\title{
А. А. Романов
}

\section{Естественнонаучные исследования раннесредневековых напластований городища Уфа-2}

Городище Уфа-2 является одним из опорных памятников лесостепного Предуралья. Археологические исследования на городище проводились с 1953 по 2018 г. Всего было исследовано более 2893 м². Мощность культурного слоя достигает 3-4 м. Памятник соотносится с населением преимущественно бахмутинской (чандарский тип), турбаслинской и именьковской (романовский тип) культур. Менее представлен керамический материал кушнаренковской археологической культуры и караякуповского типа. Согласно данным исследований, памятник датируется эпохой средневековья, но основная масса материалов, выявленных в культурном слое, относится к периоду с IV по IX век н.э. В ходе полевых археологических работ была установлена планировка жилой части памятника, размеры и период функционирования фортификационных сооружений. При изучении городища было проведено большое количество разнообразных естественнонаучных исследований, однако попыток сведения полученных результатов в единый очерк не предпринималось. Для дальнейшего изучения городища необходимо собрать воедино выводы, полученные в ходе полевых работ и естественнонаучных исследований. В процессе исследований остеологических материалов получены данные о составе и возрастной структуре стада, роли охоты и рыбной ловли в жизнеобеспечении населения. Производящее хозяйство включало изготовление керамической посуды и изделий из камня, косторезное и кожевенное ремесло, литье из бронзы и прядение шерсти. Изучение изделий из металла и бус помогло установить торговые связи населения Уфимского полуострова с регионами Поволжья, Прикамья, Сирии, Крыма и Египта. На основании палинологических данных были установлены этапы сукцессии растительных сообществ. В финальной части данной работы сформулированы актуальные направления дальнейшего изучения городища.

Ключевые слова: лесостепное Предуралье, городище Уфа-2, раннее средневековье, бахмутинская культура, турбаслинская культура, кушнаренковская культура, романовский тип.

\section{Введение}

Городище Уфа-2, археологический памятник эпохи средневековья, был открыт П. Ф. Ищериковым в 1953 г. при наблюдении за земляными работами на улице Пушкина. Оно располагается в историческом центре Уфы на участке, ограниченном улицами Новомостовая, 3. Валиди (ранее ул. Фрунзе), Пушкина и проспектом Салавата Юлаева, на мысу, образованном двумя оврагами, по которым ранее протекали ручьи (рис. 1). Высота городища над уровнем р. Белая, как сообщает П. Ф. Ищериков [14, с. 97], составляет около 40 м. Площадь мыса 2,53 га [21, с. 14]. Территория городища неоднократно подвергалась перепланировке в период функционирования современного города Уфа, что привело к утрате большой части культурного слоя в южной и юго-восточной части (рис. 2) при постройке автомобильного моста через р. Белая [21, с. 3]. На памятнике были выявлены находки, соотносимые с имендяшевским типом финала эпохи раннего железа - начального этапа раннего средневековья, бахмутинской (чандарский тип), турбаслинской, кушнаренковской и именьковской (романовский тип) культурами и караякуповским типом эпохи раннего средневековья, чияликской культурой и древностями Золотой Орды эпохи развитого средневековья, а также этнографическим периодом существования современного города Уфа. Однако основной культурный слой на памятнике сформировался, по всей видимости, в эпоху раннего средневековья. Исходя из этого в данной работе мы будем обращаться к материалам этого периода.

(C) Романов A. A., 2020 
Электронный научный журнал (Online). ISSN 2303-9922. http://www.vestospu.ru

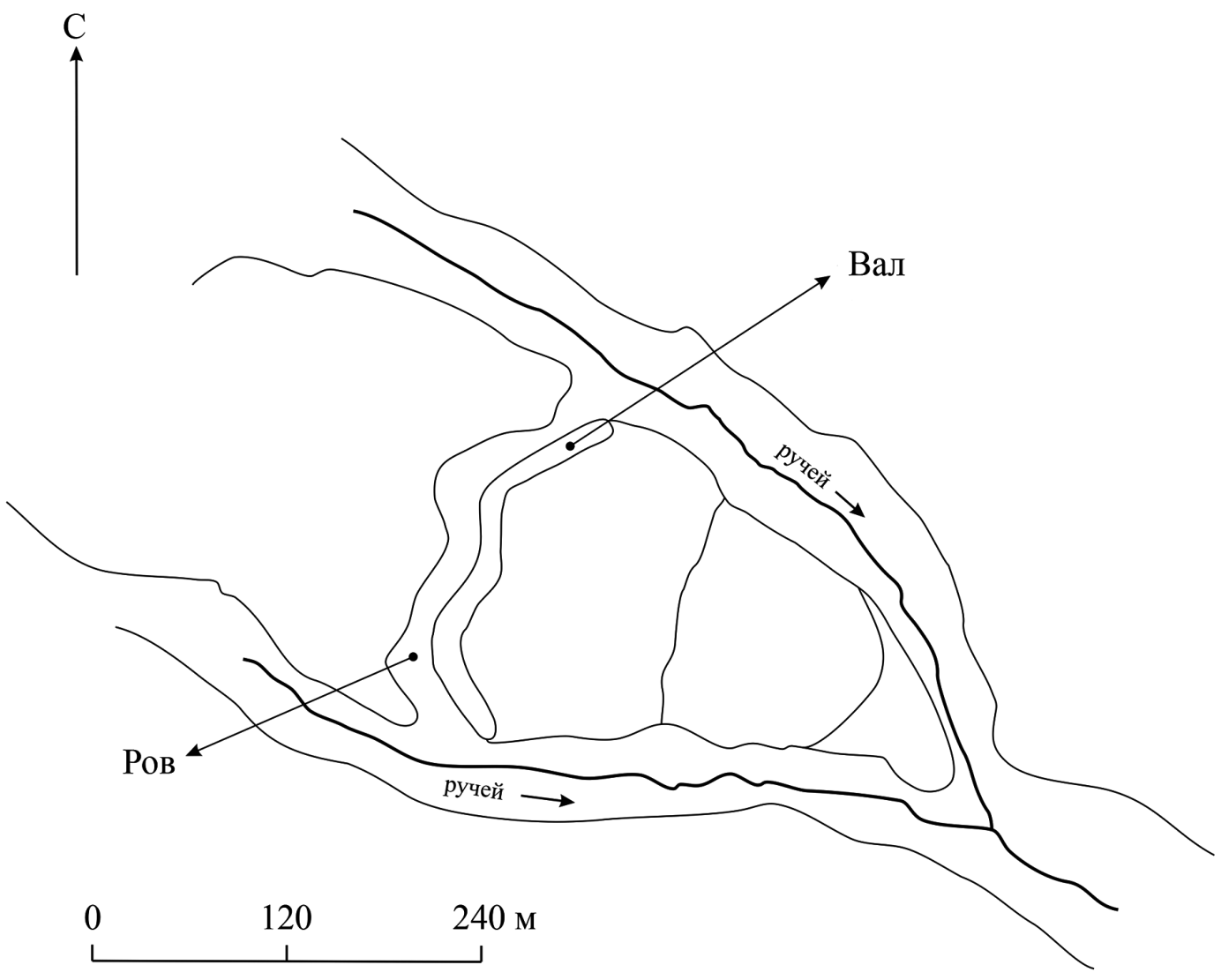

Рис. 1. План городища Уфа-2. Прорисовка с карты 1745 г. (с дополнениями автора) $[21$, с. 61, рис. 4$]$

История археологического изучения памятника описывалась ранее в отчетах и монографиях, посвященных результатам ежегодных полевых работ, однако единого полного очерка до сих пор не существует. Также стоит отметить, что во всех этих работах недостаточно внимания уделено результатам естественнонаучных исследований, проводившихся на материалах этого памятника. Кроме того, ранее не делались попытки сведения воедино планов всех раскопов городища, что наряду с различными методиками исследования (разные размеры квадратов и глубина выемки условных горизонтов) осложняет совокупный анализ естественнонаучных и археологических материалов, полученных на разных участках памятника, и, как следствие, историческую интерпретацию естественнонаучных материалов. В статье ставится задача дать сводное описание проведенных ранее археологических исследований. Решение этой задачи необходимо для более глубокого осмысления естественнонаучных данных, полученных на городище, соотнесения остеологических материалов с населением различных археологических культур и типов, проживавших на памятнике в раннесредневековый период его функционирования. Также будут собраны в единую систему выводы, полученные ранее в ходе различных естественнонаучных исследований, и сформулированы перспективные направления для дальнейшего изучения жизнеобеспечения населения городища.

\section{Основная часть}

Полевые археологические исследования на городище проводились в 1957-1958, 1990 и 2006-2017 гг. (рис. 3). Всего на городище было изучено более 2893 м². Данные по площади раскопов и методике проведения изысканий представлены в таблице 1. Первые разведочные работы на памятнике были проведены П. Ф. Ищериковым и Н. А. Мажитовым в 1957-1958 гг. 
Электронный научный журнал (Online). ISSN 2303-9922. http://www.vestospu.ru

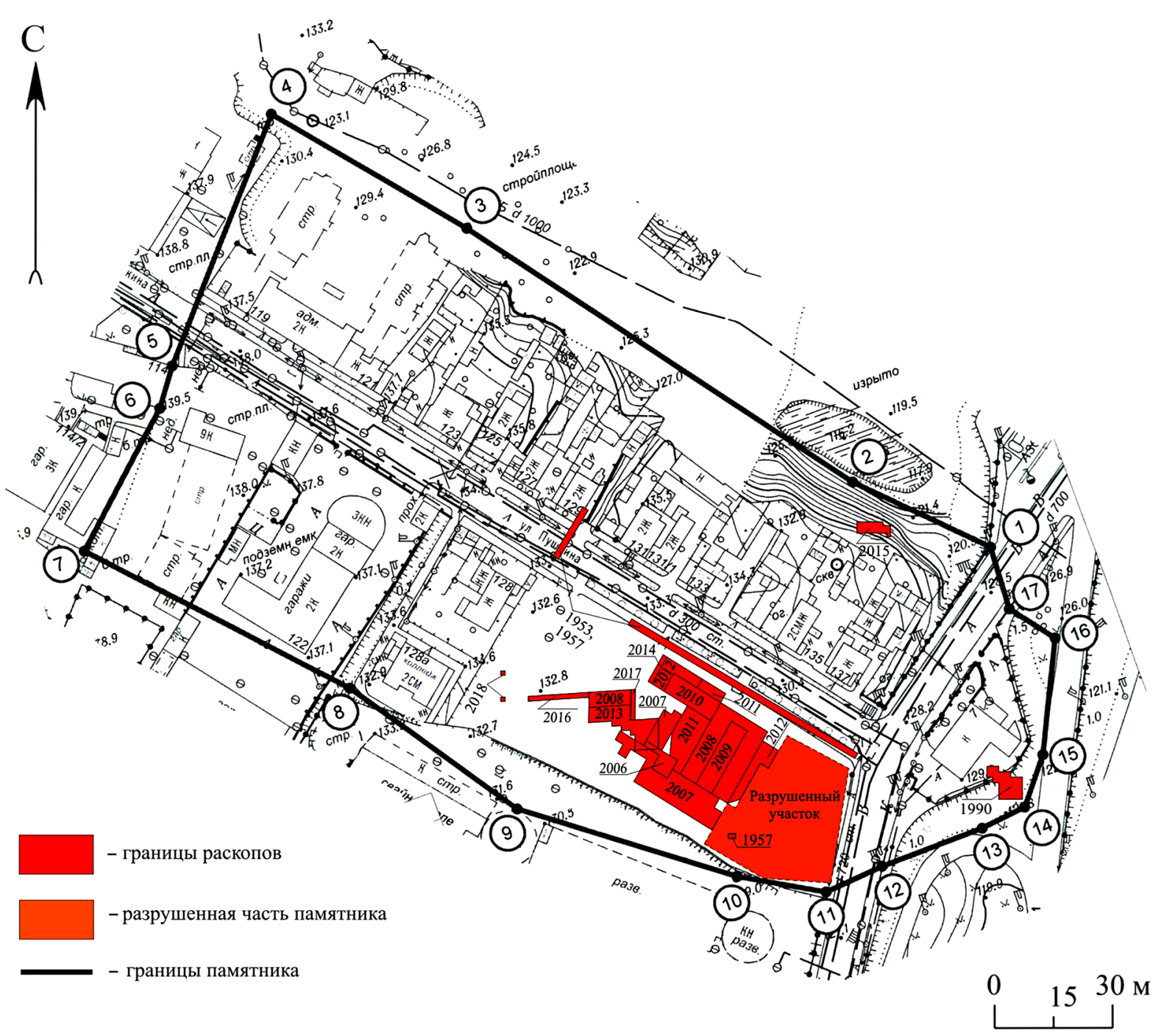

Рис. 2. Схема расположения исследованного и разрушенного участков памятника

$[3$, т. 2 , рис. $8 ; 25$, рис. $1 ; 56$, рис. $4 ; 62$, рис. 56$]$

Исследования позволили получить детальную стратиграфию культурных напластований поселения и дали богатый археологический материал, представленный керамическими сосудами нескольких типов, костяными наконечниками стрел и накладками на лук, пряслицами и грузилами для рыболовных сетей, бронзовыми браслетами, стеклянными и янтарными бусами и раковинами каури. На основании находки парфянской геммы были даны первые хронологические границы существования памятника - с рубежа эр до VII в. н.э. [13, с. 17]. П. Ф. Ищериков на территории памятника выявил 15 погребений, соотнесенных в дальнейшем с бахмутинской и турбаслинской археологическими культурами [13]. В ходе полевых работ 1958 г. Н. А. Мажитовым уточнены хронологические рамки существования городища: с I в. н.э. по IX-X вв. н.э. $[21$, c. $8-10]$.

В 1990 г. В. В. Овсянниковым был заложен раскоп в восточной части мыса (данный участок в последующем разрушен при постройке проспекта С. Юлаева и южного выезда из города) и получены первые данные о распределении керамического материала в культурном слое. На основании расположения керамики различных типов сделан вывод, что в процессе существования городища происходила постепенная смена его населения. Местное население замещалось пришлым, пришедшим с правобережья среднего тече- 
Электронный научный журнал (Online). ISSN 2303-9922. http://www.vestospu.ru

ния р. Белая [24]. В ходе исследования Овсянников уточняет периодизацию памятника (V-VII вв. н.э.) и разделяет период существования городища на три этапа - период освоения территории и закладки хозяйственных ям (V в. н.э.); второй этап заселения территории (V-VI вв. н.э.) и завершающий этап существования городища (VII в. н.э.). Автор не исключает вероятности, что городище продолжало функционировать вплоть до VIII в. н.э., так как в верхних слоях выявляется керамика караякуповской культуры, соотносимая с этим периодом [24, с. $69-70]$.

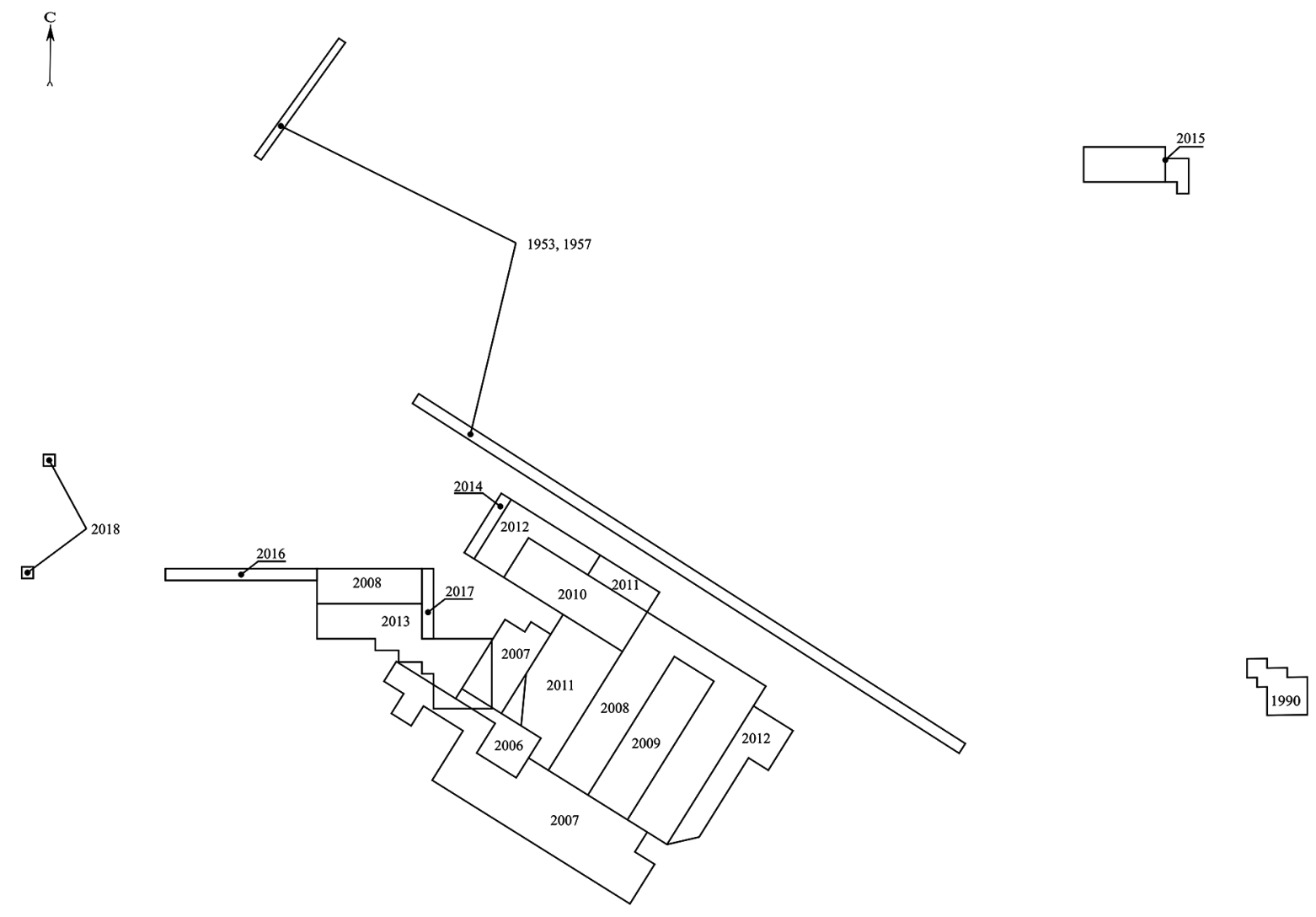

\begin{abstract}
$\underbrace{0} \cdot 1^{10 \mathrm{~m}}$
1957

Рис. 3. Схема расположения раскопов 1957-2018 гг. (по отчету И. А. Шутелевой, с дополнениями) $[3$, т. 2 , рис. $8 ; 25$, рис. $1 ; 56$, рис. $4 ; 61$, рис. 56$]$
\end{abstract}

С 2006 по 2012 г. планомерные раскопки на городище проводились силами исторического факультета Башкирского государственного университета. Полевые исследования поселенческой части памятника в 2006-2010 г. велись квадратами 4×4 м. Выемка грунта производилась условными горизонтами по 20 см (табл. 1). Изученный участок дал богатый археологический материал, соотнесенный Н. А. Мажитовым с бахмутинской, турбаслинской, караякуповской и кушнаренковской культурами [21, с. 46-47]. В ходе исследования 2007 г. были выявлены настилы из деревянных плах, вероятно выполнявшие функцию мостовых [22, с. 25-26]. В 2008 г. на городище было заложено два раскопа. Раскоп № 1 располагался на поселенческой части памятника [10, с. 103]. В его пределах были выявлены пять хозяйственно-жилищных комплексов (ХЖК). Два строения (ХЖК № 1 и № 5) фиксируются в нижних слоях раскопа вплоть до материкового слоя, в который они были углублены. Еще три (ХЖК № 2-4) - в пределах средней части отложений [10, с. 64-71]. Хозяйственно-жилищные комплексы представляли собой постройки кар- 
Электронный научный журнал (Online). ISSN 2303-9922. http://www.vestospu.ru

касно-столбового типа [10, с. 67] и имели, по всей видимости, дощатый пол [10, с. 6465]. В пределах контуров жилищ были выявлены хозяйственно-бытовые ямы и скопления керамики турбаслинской и бахмутинской культур. Р. Б. Исмагилов выделяет также керамику турбаслинско-бахмутинского типа [10, с. 67]. Все строения были сооружены, вероятно, приблизительно в одно время, на раннем этапе существования городища. Из пяти выявленных в пределах раскопа 2008 г. ХЖК четыре прекращают свое существование на уровне 5 горизонта, а один - на уровне 7 горизонта. Продолжают фиксироваться остатки деревянных мостовых. Все деревянные настилы располагаются в пределах 6-7 стратиграфических горизонтов. Отдельные участки настила имели смычки и, вероятно, являлись частями единой системы [10, с. 73-74].

Раскоп № 2 расположен западнее площадки исследований 2006-2008 гг. (рис. 3). На данном участке впервые на городище применяется новая координатная сетка, ориентированная не по квартальной застройке, а по линии северо-восток - юго-запад [50, с. 10]. Целью данного раскопа было изучение строения фортификационного сооружения (вала) городища [50, с. 10]. Площадь участка была разделена на квадраты $2 \times 4$ м (табл. 1). Раскоп выявил сложную структуру оборонительных сооружений. В ходе исследования удалось установить, что вал состоял из древесно-земляных конструкционных сооружений, расположенных в шахматном порядке [50, с. 60]. Ранее на основании исследования планов уфимской крепости и ее окрестностей было установлено, что вал имел М-образную форму (рис. 1). По внешнему краю шла линия бермы, предотвращавшая засыпку рва с внешнего слоя [50, с. 60]. Также были взяты 9 образцов из южной и 4 образца из северной стенок раскопа крепостной стены (вала) и 3 образца участка культурного слоя на месте выявления деревянных настилов. В качестве объектов для исследования были выбраны кусочки угля и дерева. Полученные данные показывают, что располагавшаяся под насыпью вала погребенная почва сформировалась в пределах первой половины II начала III в. н.э. Вышележащие напластования датируются в пределах IV-VII вв. н.э. [52, с. 51-55]. Полученные Ф. А. Сунгатовым в ходе раскопок 2008 г. материалы были отнесены к хронологическому интервалу с V по VIII в. н.э. [50, с. 60]. Период функционирования деревянных настилов, согласно этому исследованию, может быть датирован второй половиной VI - первой половиной VII в., т.е. в пределах одного столетия [52, c. 44].

Раскоп 2009 г. был заложен между линиями раскопа № 12008 г. [51, с. 8-10]. В пределах раскопа выявлены 5 хозяйственно-жилищных комплексов, являющихся продолжением строений, исследованных в 2008 г. Строения фиксируются в пределах 412 (ХЖК-1-ХЖК-4) и 2-9 (ХЖК-5) горизонтов раскопа 2009 г. [51, с. 36-43]. Также было продолжено изучение остатков деревянных настилов [51, с. 44]. Общая схема строений и мостовых, выявленных в 2008-2009 гг, дана в отчете о результатах раскопок на памятнике в 2009 г. [51, рис. 151]. В дальнейшем подробное описание архитектурного облика городища приведено в монографии Ф. А. Сунгатова и коллег [53, с. 106-116].

Интересным наблюдением является вывод о различиях в спецификации хозяйственной деятельности обитателей исследованных ХЖК [51, с. 87]. Исследователи выделяют два строительных горизонта в толще культурного слоя. Первый был выявлен на уровне погребенной почвы, второй несколько более поздний [51, с. 87]. Отмечается, что все хозяйственно-жилищные комплексы неоднократно подвергались перестройке. Обнаруженные зольные слои большой мощности дают возможность предполагать, что причиной перестройки послужили пожары, несколько раз уничтожавшие жилища [51, с. 88]. Следы таких пожарищ выявлены в дальнейшем по результатам палинологических исследований Р. Г. Курмановым на месте раскопов 2012 [16, с. 178-183] и 2017 гг. [17, с. 144—145]. 
Электронный научный журнал (Online). ISSN 2303-9922. http://www.vestospu.ru

В ходе полевого сезона 2010 г. найдены 5 хозяйственно-жилищных комплексов, один из которых является продолжением строения, выявленного в 2008 г., а еще четыре - новыми объектами [50, с. 12-24]. Было выявлено большое количество керамического материала бахмутинской, турбаслинско-бахмутинской и развитого этапа кушнаренковской культурных групп. Кроме того, выявлены фрагменты импортной керамики раннеболгарского типа [49, с. 27-28]. Среди индивидуальных находок - костяные изделия (наконечники стрел и накладки на лук, проколки, сунак, пряжки), изделия из камня (оселки и подвески), изделия из металла (ножи, наконечники стрел), остатки берестяного туеса, керамические изделия (пряслица, тигли, сопла, сосуды малых форм) [49, с. 25].

Таблица 1

Характеристики раскопов, заложенных на городище Уфа-2, по годам

\begin{tabular}{|c|c|c|c|c|c|}
\hline Год & Автор исследования & $\begin{array}{c}\text { Общая } \\
\text { площадь } \\
\text { раскопа, м² }\end{array}$ & $\begin{array}{c}\text { Мощность } \\
\text { культурного } \\
\text { слоя }\end{array}$ & $\begin{array}{c}\text { Размер } \\
\text { квадратов, м }\end{array}$ & $\begin{array}{c}\text { Методика } \\
\text { выемки } \\
\text { грунта }\end{array}$ \\
\hline 1957 & П. Ф. Ищериков [14] & 15 & до 3 м & & \\
\hline 1958 & Н. А. Мажитов $[22$, с. $4-5]$ & 20 & до 3 м & & \\
\hline 1968 & М. Х. Садыкова [21, с. 4-5] & \multicolumn{4}{|c|}{ Отчет не сохранился } \\
\hline 1990 & В. В. Овсянников [24] & 92 & $1,5 \mathrm{M}$ & & \\
\hline 2006 & Н. А. Мажитов [21, с. 17, 27] & 92 & до $3,5 \mathrm{M}$ & $4 \times 4$ & по $18-20 \mathrm{~cm}$ \\
\hline 2007 & Н. А. Мажитов $[22$, с. 3$]$ & 600 & до 4 м & $4 \times 4$ & по $18-20 \mathrm{~cm}$ \\
\hline \multirow{2}{*}{2008} & Р. Б. Исмагилов [10, с. 9-10] & 608 & до 3 м & $4 \times 4$ & \multirow{2}{*}{ по $18-20 \mathrm{~cm}$} \\
\hline & Ф. А. Сунгатов [50, с. $10-11]$ & 88 & вал & $2 \times 4$ & \\
\hline 2009 & Ф. А. Сунгатов [51, с. 8-10] & 240 & до 3 м & $4 \times 4$ & по $18-20 \mathrm{~cm}$ \\
\hline 2010 & Р. Б. Исмагилов [49, с. 11] & 160 & до 3 м & $4 \times 4$ & по $18-20 \mathrm{~cm}$ \\
\hline 2011 & В. И. Мухаметдинов [54, с. 12] & 352 & Отчет в нас & оящий момент & не написан \\
\hline \multirow{2}{*}{2012} & \multirow{2}{*}{$\begin{array}{l}\text { Р. Р. Русланова (Тамимдарова) }[54, \\
\text { с. } 12 ; 42, \text { с. } 9]\end{array}$} & 144 & \multirow{2}{*}{ до 3 м } & $2 \times 2$ & по 10 см \\
\hline & & 125 & & $4 \times 4$ & по $18-20 \mathrm{~cm}$ \\
\hline 2013 & $\begin{array}{l}\text { И. А. Шутелева, Н. Б. Щербаков } \\
{[63, \text { с. } 2-18]}\end{array}$ & 152 & вал & $2 \times 2$ & по $8-10$ см \\
\hline 2014 & М. Р. Шамсутдинов [54, с. 12-14] & 25 & до 3 м & $2 \times 2$ & по $8-10$ см \\
\hline $2015 \mathrm{a}$ & Е. В. Русланов [37, с. 12-13] & 20 & до $3,5 \mathrm{M}$ & $2 \times 2$ & по $15-20 \mathrm{~cm}$ \\
\hline 20156 & И. А. Шутелева [61, с. 8-17] & 84 & до 3,7 м & $2 \times 2$ & по $8-10$ см \\
\hline 2016 & М. Р. Шамсутдинов [55, с. 12-16] & 52 & ров & $2 \times 2$ & по 20 см \\
\hline 2017 & $\begin{array}{l}\text { О. С. Белявская (Крапачева) [3, т. } 1 \text {, } \\
\text { с. } 15-17]\end{array}$ & 24 & до 3 м & $2 \times 2$ & по $10-15 \mathrm{~cm}$ \\
\hline
\end{tabular}

Отчет о полевых исследованиях в 2011 г. в настоящий момент не написан [54, с. 12]. В 2012 г. изменена методика проведения полевых археологических работ на памятнике. Применявшиеся ранее квадраты $4 \times 4$ м были разделены до квадратов $2 \times 2$ м с привнесением дополнительной буквенной маркировки (a, б, в, г), уменьшена глубина прокопки условных горизонтов с 20 до 10 см, что позволило повысить точность фиксации находок $[42$, с. 9]. Керамический комплекс, как и в прошлые годы раскопок, представлен преимущественно керамикой турбаслинской и бахмутинской культур, а также смешанного турбаслинско-бахмутинского типа. Кроме того, в раскопе 2012 г. исследователями обнаружена импортная раннеболгарская и ломоватовская керамика [42, с. 113-117]. Часть раскопа была законсервирована на уровне 8 горизонта. Раскопки на этом участке продолжили в 2014 г. [42, с. 10, 20]. 
Электронный научный журнал (Online). ISSN 2303-9922. http://www.vestospu.ru

Некоторые вопросы культурной атрибуции керамики турбаслинско-бахмутинской группы уточнены в 2017 г. В. В. Овсянниковым [25, с. 35-36]. Им выделена керамика романовского типа именьковской культуры. К подобному заключению приходили ранее и некоторые другие исследователи [20, с. 63].

В 2013 г. вновь был заложен разрез вала и прилегающей к нему территории [62, c. 2-3; рис. 49-62]. Участок раскопа разделили на квадраты $2 \times 2$ м. Выемка грунта производилась условными горизонтами по 20 см (табл. 1). Раскоп ориентирован согласно координатной сетке раскопа № 22008 г., т.е. по линии северо-восток - юго-запад (рис. 3). Существует нестыковка в расположении раскопа 2013 г. на планах городища. В схеме, предложенной авторами отчета [62, рис. 87], данный участок смещен западнее и не перекрывается с площадками 2006-2007 гг., однако на уточненных схемах, представленных в более поздних работах [55, рис. 5], видно, что часть раскопа 2013 г. заходит на рекультивированные отложения ранее исследованных квадратов (рис. 3). Таким образом, остеологические материалы, полученные в этих квадратах, не могут быть однозначно привязаны к ненарушенным отложениям и, следовательно, должны быть исключены из выборки. В ходе полевых исследований 2013 г. была выявлена керамика бахмутинской, турбаслинской культур, турбаслинско-бахмутинского, кушнаренковского и караякуповского типов, а также импортная гончарная керамика [62, с. 54].

В 2014 г. продолжались раскопки на законсервированном ранее участке 2012 г. В ходе исследования была сохранена методика 2012 г. (использовалась квадратная сетка $2 \times 2$ м с дополнительной буквенной маркировкой, выемка грунта производилась условными горизонтами по 8-10 см). Как и ранее, основной материал связан с бахмутинской и турбаслинской культурами, романовским типом именьковской культуры (турбаслинско-бахмутинская группа), реже встречалась керамика кушнаренковской культуры и караякуповского типа [54, с. 126-129]. Индивидуальные находки представлены изделиями из кости и рога (наконечники стрел, накладки на лук, орнаментиры, проколки), глины (пряслица, тигли), камня (оселки и песты), металла (бронзовые пряжки, фибулы и подвески, фрагмент железного ножа), а также стеклянными бусами [56, с. 85-99]. Исследованный участок был датирован началом V - XIV в. н.э. [53, с. 130], однако в отчете отсутствует описание находок, которые соотносились бы с периодом с X по XIV в. н.э. Все выявленные находки соотносятся или с эпохой раннего средневековья, или с этнографическим периодом существования современного г. Уфа [56, с. 85-120].

В 2015 г. на городище заложили два раскопа на периферии поселения, на северо-восточном склоне занимаемого им мыса [37, с. 4; 62 с. 6]. Участки были ориентированы согласно координатной сетке, применявшейся в 2008 и 2013 гг., но имели некоторые отличия в методике проведения полевых работ. Выемка грунта раскопа № 1 производилась условными горизонтами по 15-20 см, а раскопа № 2 - по 8-10 см (табл. 1). Важно обратить внимание на то, что оба раскопа были заложены на осыпающемся склоне мыса, подверженном сильному антропогенному воздействию в период существования современного города Уфа [37, с. 12]. В ходе исследования раскопа № 1 получена большая масса находок, основу которых, как и ранее, составляли керамический материал и кости животных. Согласно представленному отчету, достаточно большая часть исследованного культурного слоя не была потревожена и полученные материалы могут быть использованы при проведении дальнейших исследований [37, с. 14-22]. В нижней части культурного слоя зафиксирована хозяйственная яма, анализ материалов из которой дал основание соотнести период ее функционирования с ранним этапом существования городища Уфа-2 (V-VI вв. н.э.) [34, с. 339]. 
Электронный научный журнал (Online). ISSN 2303-9922. http://www.vestospu.ru

На материалах раскопа № 12015 г. было продолжено изучение керамики, выявленной в культурном слое городища. В ходе анализа фрагментов 95 сосудов керамический материал был разделен по его принадлежности к культурным группам проживавшего здесь населения - бахмутинской $(49,5 \%)$, турбаслинской $(26,3 \%)$, романовского типа именьковской культуры (4,2\%), кушнаренковской и караякуповской $(22,1 \%)$ [2, с. 68-69].

Культурный слой раскопа № 2 в 2015 г., согласно отчету И. А. Шутелевой, подвергся значительной антропогенной нагрузке периода функционирования современного города Уфа [61, с. 35-62]. В материалах встречены артефакты, соотносимые с двумя периодами - эпохой раннего средневековья и XIX-XX вв. н.э. Помимо фрагментов керамических сосудов и костей животных получены пряслица, накладки на лук и наконечники стрел. Анализ керамики показал, что раннесредневековая часть культурных напластований соотносится с двумя археологическими культурами - бахмутинской (IIIVII вв. н.э.) и турбаслинской (V-VIII вв. н.э.) [61, с. 82-83].

В 2016 г. был заложен раскоп фортификационного сооружения (рва) городища под руководством М. Р. Шамсутдинова [55, с. 12]. Верхний слой на данном участке сложен строительным и бытовым мусором, бетонными плитами и песчано-гравийной подушкой, он был снят экскаватором [55, с. 13]. Проведение полевых археологических работ осложняли грунтовые воды, подмывавшие стенки раскопа и приводившие к их обрушениям. Это же затрудняло выемку грунта и фиксацию находок в нижней части отложений. Однако основные цели раскопок были достигнуты. Удалось установить размеры (ширину и глубину) и конфигурацию рва [55, с. 72]. Анализ полученных в ходе полевого исследования материалов, а также напластований заполнения рва позволил автору отчета сформировать гипотезу, что ров функционировал только на начальном этапе существования памятника (IV_-VI вв. н.э.) и далее был целенаправленно засыпан [55, с. 12-16, 72 - 73].

Необходимо более подробно рассмотреть выделенные в ходе исследования этапы засыпки крепостного рва, так как это имеет принципиальное значение для дальнейшего исследования полученных в этих напластованиях остеологических материалов. Согласно данным, представленным в отчете [55, с. 72], заполнение рва на уровне пластов 8-11 представлено слоем плотной глины с затеками темного грунта (слой № 19), что соответствует слою, который сформировался при первом засыпании рва. В пределах пласта 8 происходит совмещение слоев, морфологически соотносимых с первым и вторым этапами засыпания рва [55, с. 72], поэтому полученные здесь материалы правильно будет считать перемешанными. Второй этап (слой № 7) был соотнесен автором раскопа со слоем грунта средней плотности коричневого оттенка, состоящего из неравномерного перемеса глины и серозема [55, с. 72]. Эта прослойка начинает фиксироваться на уровне пласта 5. Основная масса слоя находится в пределах 6-7 пластов [55, с. 28-34]. При этом на уровне седьмого горизонта выделяются слои как первого, так и второго этапов засыпания рва, а потому соотношение костей животных в отсутствие их разделения при проведении полевых археологических работ по принадлежности к конкретным напластованиям нужно рассматривать как перемешанное. В пределах же пятого горизонта были зафиксированы современные вкопы, затронувшие три квадрата из семи обследованных на уровне этого пласта [55, с. 28-29]. Таким образом, опираться на полученные из седьмого пласта материалы невозможно. Пласты 1-5 были сильно потревожены в ходе хозяйственной деятельности в XX в., и опираться на полученные из них материалы тоже не представляется возможным. Следовательно, достоверно соотносить со вторым этапом засыпания рва можно только кости, полученные на уровне пласта 6.

В 2017 г. полевые исследования на городище продолжались под руководством О. С. Белявской. В ходе исследования получена обширная коллекция археологических и ар- 
Электронный научный журнал (Online). ISSN 2303-9922. http://www.vestospu.ru

хеозоологических материалов. Данный участок расположен вблизи исследовавшихся в 2008, 2013 и 2016 гг. фортификационных сооружений (вала и рва). В пределах изучаемого участка выявлены жилище каркасно-столбового типа и хозяйственная яма, использовавшаяся жителями поселения, как считает автор отчета, для хранения продуктов [3, т. 1, с. 69]. Археозоологические материалы, полученные на этом раскопе, играют важную роль в исследованиях различных аспектов хозяйственной деятельности населения городища.

Кроме того, О. С. Белявской и А. С. Проценко была проанализирована керамика, полученная на городище Уфа-2 в 2017 г. В ходе анализа выявлена закономерность в залегании керамического материала по глубине раскопа. Согласно полученным данным, на нижних пластах раскопа бахмутинская керамика и керамика турбаслинского и романовского типов залегает совместно. При этом отмечается количественное преобладание первой. На втором этапе отмечается увеличение доли турбаслинской и романовской керамики. На финальном этапе в керамическом материале появляется керамика кушнаренковского типа [4]. Исходя из этого О. С. Белявская и А. С. Проценко уточняют выдвинутое В. В. Овсянниковым и Ф. А. Сунгатовым [26] предположение о том, что угасание укрепленных поселений бахмутинской культуры связано с приходом на территорию лесостепного Предуралья населения романовского типа. По мнению авторов [4], данное утверждение не отражает реальность, так как в культурном слое городища Уфа-2 бахмутинская и романовская керамика продолжительное время залегают совместно; угасание городища происходило под влиянием военизированных племен кушнаренковской культуры.

Таким образом, в ходе полевых археологических исследований городища было найдено и изучено большое количество археологических материалов эпохи раннего средневековья, позволивших установить культурную принадлежность проживавшего здесь населения, основные направления его хозяйственной деятельности, торговые контакты с различными регионами в Европе и Азии. Однако немало вопросов по-прежнему требуют решения, в частности о непрерывности функционирования памятника.

В настоящий момент в научной литературе, посвященной городищу, можно встретить две точки зрения на непрерывность его функционирования. В коллективной монографии под общей редакцией Ф. А. Сунгатова [53, с. 14-19] отстаивается позиция Н. А. Мажитова, согласно которой городище Уфа-2 продолжало функционировать как крупное укрепленное поселение вплоть до позднего средневековья. Авторы обосновывают малое количество материалов чияликской культуры и эпохи Золотой Орды хозяйственной деятельностью жителей современной Уфы [53, с. 14-19].

Согласно другой точке зрения, период функционирования городища Уфа-2 как крупного, хорошо укрепленного поселения нужно датировать по наиболее массово встречающейся керамике бахмутинского, турбаслинского и романовского типов в пределах IV/V-IX вв. [43, с. 165]. В дальнейшем, считают авторы статьи, площадка памятника была заброшена. Обжитая же часть мыса представляла собой небольшое, возможно сезонное, поселение племен чияликской культуры [43, с. 165-166].

Подробное рассмотрение данной дискуссии выходит за рамки настоящей работы. Важно отметить, что эта дискуссия в настоящий момент не завершена и единая позиция не выработана. В контексте проводимых автором статьи исследований остеологического материала стоит отметить, что основная масса выявленных на всей толщине культурного слоя памятника артефактов датируется с IV по IX в. н.э. Эти же временные рамки были получены при радиоуглеродном датировании. Таким образом, остеологические материалы, полученные из этих напластований, должны трактоваться как отходы жизнедеятельности проживавшего в этот период населения бахмутинской (чандарский тип), турбас- 
Электронный научный журнал (Online). ISSN 2303-9922. http://www.vestospu.ru

линской, именьковской (романовский тип) и кушнаренковской культур [3, т. 1, с. 4; 34 , c. $339-340 ; 37$, c. $58 ; 62$, с. 54$]$.

\section{Естественнонаучные исследования городища Уфа-2}

В процессе изучения на материалах городища проведено большое количество разнообразных анализов и исследований (табл. 2), уточняющих не только различные аспекты жизнедеятельности его населения, но и природные характеристики окружающей памятник местности.

Таблица 2

Анализы, проведенные на материалах городища Уфа-2 в разные годы исследований

\begin{tabular}{|c|c|c|c|c|c|c|c|c|c|c|c|}
\hline Год & I & II & III & IV & $\mathrm{V}$ & VI & VII & VIII & IX & $X$ & XI \\
\hline 1958 & & & & & & & & & $+^{29}$ & & \\
\hline 1990 & & & & & & & & & +30 & & \\
\hline 2007 & $+^{1}$ & $t^{2}$ & $+{ }^{13}$ & & & & & \multirow{2}{*}{$+^{25}$} & & & \\
\hline 2008 & & $t^{2}$ & $++^{14}$ & & & & & & & & $+^{3}$ \\
\hline 2011 & & & & $+{ }^{16}$ & & & & & & & \\
\hline 2012 & & $+4,5$ & & +17 & $+^{20}$ & & & & & +33 & \\
\hline 2013 & & $+^{6}$ & & & & $+^{22}$ & & & & & \\
\hline 2014 & & $++^{7,8}$ & & $+{ }^{18}$ & & & & $+{ }^{26}$ & & & \\
\hline $2015 a$ & & $+9,10$ & & & & $+^{23}$ & $+^{24}$ & +27 & $+^{31}$ & $+^{34}$ & \\
\hline 20156 & & & $+14,15$ & & & & & & & & \\
\hline 2016 & & $+^{5}$ & & & & & & & & & \\
\hline 2017 & & $+{ }^{11,12}$ & & $+{ }^{19}$ & $+^{21}$ & & & $+{ }^{28}$ & +32 & $+{ }^{35}$ & \\
\hline
\end{tabular}

Примечания: I - анализ антропологических материалов; II - анализ археозоологических материалов; III - почвохимические и микробиоморфные исследования; IV - палинологические исследования; V — анализ остатков органических материалов; VI — исследования бисера и бус; VII — анализ изотопов Sr в костях животных; VIII - палеоихтиологические исследования; IX — анализ культурной принадлежности фрагментов керамики; X - петрографический анализ каменных орудий; XI — радиоуглеродное датирование. $1-$ [19]; $2-$ [46]; $3-$ [52]; $4-$ [44]; $5-$ [28]; 6 - результаты собственных исследований. В настоящий момент не опубликованы; $7-[30] ; 8-[56$, с. $168-176] ; 9-[29] ; 10-[37$, c. 80-95]; $11-[27] ; 12-[32] ; 13-[47] ; 14-[7] ; 15-[48] ; 16-[18] ; 17-[16] ; 18-[54$, c. $123-167] ; 19-$ [17]; $20-[11] ; 21-[12] ; 22-[40] ; 23-[41] ; 24-[23] ; 25-[57] ; 26-[59] ; 27-[60] ; 28-[58] ;$ $29-[15] ; 30-[24] ; 31-[2] ; 32-[4] ; 33-[39] ; 34-[38] ; 35-[8]$.

\section{Палинологические исследования}

Одним из наиболее значимых направлений в изучении памятника являются палинологические исследования, результаты которых изложены в работах Р. Г. Курманова и А. Р. Ишбирдина. В статье 2015 г. [18] изложены выводы о смене растительности на территориях, окружавших городище, по материалам, полученным на месте раскопа 2011 г. Согласно полученным данным, начальный период функционирования городища характеризуется ландшафтами, представленными широколиственными лесами с доминированием липы, дуба и открытыми пространствами опушек и полян. Влияние человеческой деятельности на ландшафт в этот период не обнаруживается. Далее отмечается увеличение доли синантропных и рудеральных видов однолетних травянистых растений. В последующем наблюдается чередование периодов, в течение которых происходит увеличение доли пыльцы растений, характерных для широколиственных лесов, и хронологических отрезков с увеличением доли пыльцы рудеральных видов сообществ, маркирующих увеличение хозяйственного освоения территории [18, с. 108-109]. Отмечается, что за время функционирования поселения произошло несколько крупных пожаров [18, с. 108]. 
Электронный научный журнал (Online). ISSN 2303-9922. http://www.vestospu.ru

В статье Р. Г. Курманова [16] изложены результаты изучения сукцессий растительных сообществ методом споро-пыльцевого анализа, проведенного на материалах, полученных на месте раскопа 2012 г. В целом результаты этой работы не противоречат выводам, полученным на материалах раскопа 2011 г., дополняя их. Так, автором было выделено шесть периодов демутации растительных сообществ, чередовавшихся с периодами максимума комплексов луговых и опушечных, рудеральных и пасквальных сообществ [16, c. 183]. Отмечается два периода увеличения пыльцы растений, маркирующих зарастающие пожарища [16, с. 180], и периоды заболачивания окружающей территории [16, c. 181].

Перекрестный анализ данных двух исследований [16; 18] однозначно подтверждает правомерность выделения шести периодов смены растительных сообществ. Кроме усиливающейся антропогенной нагрузки на биоценозы, выраженной в увеличении обилия рудеральной и пасквальной растительности, фиксируются и естественные климатические изменения. Выявление напластований, в которых выше концентрация пыльцы растений, произрастающих на пожарищах, подтверждает, как отмечалось выше, наблюдение археологов о двух строительных горизонтах, обнаруженных на памятнике и связанных, вероятно, именно с крупными пожарами [51, с. 88]. В данной ситуации полагаем перспективным проведение перекрестного исследования изменения состава керамического материала на этом участке раскопа и палинологических спектров с целью выявления наличия или отсутствия закономерностей в уровне антропогенной нагрузки на биоценозы и изменения в составе населения городища.

Таким образом, в ходе палинологических исследований было установлено, что на момент освоения территории городища здесь преобладали естественные ландшафты, представленные преимущественно широколиственными лесами, перемежающимися с открытыми пространствами опушек и полян. Выявленные этапы свидетельствуют, что уровень хозяйственного освоения территории не был постоянным. Исследователи выделяют четыре периода увеличения доли пыльцы синантропных и рудеральных растений, чередующихся с периодами восстановления природных растительных сообществ [18, c. 108-109]. В представленных статьях и отчетах отсутствуют выводы о палеоклиматической ситуации, существовавшей в течение периода функционирования городища, однако из представленных данных видно, что в разрезах, расположенных на наименее подверженной антропогенному влиянию окраине городища, широко представлена пыльца и споры растений, произрастающих в условиях влажного климата $[16$, с. 178 - $183 ; 18$, c. 108].

Данные палинологических исследований, проведенных на городище, несут важную информацию. Исследования показали принципиальную схожесть палиноспектров на периферии и в центральной части городища Уфа-2 [18, с. 108]. Это позволяет соотносить между собой материалы, полученные в напластованиях из разных раскопов, сравнение которых ввиду отсутствия общих планиграфических и стратиграфических схем на памятнике затруднительно.

\section{Почвенно-химические исследования}

Почвенно-химические исследования проводились Р. Р. Сулеймановым и А. А. Гольевой на участке раскопов 2007-2008 гг. и 2015 г. и позволили установить, что культурный слой формировался на основе четвертичных аллювиальных отложений в условиях изобилия водных ресурсов. Слои делятся на два типа напластований. К первому типу А. А. Гольева относит слои, сформировавшиеся в процессе постройки фортификационных сооружений и не несущие следов жизнедеятельности населения памятника. Ко вто- 
Электронный научный журнал (Online). ISSN 2303-9922. http://www.vestospu.ru

рой группе отнесены напластования, формирование которых происходило под влиянием интенсивной хозяйственной деятельности [22, с. 204-209], в том числе это относится и к погребенной почве городища [7].

\section{Исследования остатков растительного происхождения}

Данные о наличии возделывания растений населением городища были получены А. Р. Ишбирдиным [11; 12] и Р. М. Сатаевым с коллегами [46, с. 102]. Однако они не дают оснований утверждать о значительной роли растениеводства в жизнеобеспечении населения городища. В статье, посвященной изучению материалов раскопок 2007-2008 гг. [46, с. 102], имеются сведения о находке в хозяйственных ямах локальных скоплений семян мари белой. Данные скопления идентифицируются авторами как пищевые запасы или источники красителей для ткани и кож. Исследователи выдвигают гипотезу, что это растение целенаправленно культивировалось населением городища [46, с. 102]. Важную информацию несут приложенные к отчетам археологов результаты анализов материалов органического происхождения. Анализ, проведенный на материалах раскопа 2012 г. $[11$, c. 42$]$, показал, что в растительных остатках преобладают стебли осоки и злаковых, использовавшихся, вероятно, в качестве настила в жилых помещениях. Также была выявлена трава мари белой, как считает автор отчета, подготовленная для употребления в пищу или пережигания в поташ [11, с. 42]. В хозяйственной яме найдены массовые скопления семян мари белой и конопли сорной, возможно употреблявшихся средневековым населением в пищу [11, с. 42-43]. Кроме того, согласно отчету П. Ф. Ищерикова [13, c. 12-13], в культурном слое городища были обнаружены небольшие (30-35 см в диаметре) каменные жернова, вероятно использовавшиеся для перетирания зерен. На этом основании автор отчета делает вывод о важной роли земледелия в хозяйстве населения городища. Результаты исследования остатков растительного происхождения, полученных в 2017 г. со дна выявленной на городище хозяйственной ямы, в настоящий момент не опубликованы.

\section{Археозоологические исследования}

Вторым по количеству после керамического в материалах раскопок является остеологический материал. Первые данные о видовом составе остеологических материалов представлены в отчете П. Ф. Ищерикова [13, с. 12]. Основная масса исследованных костей принадлежала лошади, овце и свинье. Реже встречались останки верблюдов. Дикие виды животных представлены фрагментами костей лося, медведя, бобра, птиц и рыб. Подробные исследования на городище Уфа-2 впервые были проведены в 2007 г. Р. М. Сатаевым и В. В. Куфтериным [44]. Всего авторами проанализировано более 48000 костных фрагментов, принадлежавших 9 видам домашних и 11 видам диких млекопитающих, а также птицам и рыбам. В ходе исследования установлено, что видовой состав животных незначительно изменяется по глубине раскопа, однако общая концентрация остеологического материала распределена неравномерно и увеличивается к линии 7 по площади и 6 штыку по глубине раскопа. Стоит отметить и выявление костей животных, не характерных для Южного Приуралья, таких как сайгак, верблюд и осел. Авторы предполагают, что эти животные попали сюда с торговыми караванами из Средней Азии. Анализ возрастных групп домашнего скота позволил авторам сделать вывод о разнонаправленном характере содержания животных на городище. Так, МРС и свиньи, вероятно, содержались ради мяса, содержание КРС имело комплексный мясо-молочный характер, а лошадь преимущественно использовали как рабочее животное. Кости диких животных в материалах памятника крайне немногочисленны и составляют в совокупности $0,18 \%$ от общего количества определимых фрагментов. Преобладают кости сурка и бурого медведя [44]. 
Электронный научный журнал (Online). ISSN 2303-9922. http://www.vestospu.ru

Остеологические коллекции 2008 г. были проанализированы Р. М. Сатаевым, В. В. Куфтериным и Д. О. Гимрановым [46]. Авторы публикации представляют данные без указания квадратов и пластов раскопа, что не позволяет проанализировать наличие или отсутствие закономерностей в распределении материала. Всего было проанализировано и определено до вида или рода более 32000 костных фрагментов, принадлежавших 8 видам одомашненных и 5 видам диких млекопитающих [46, с. 102]. Особо стоит отметить указание авторов на то, что сбор материала происходил выборочно. Обобщая данные раскопок 2007 и 2008 гг, авторы указывают, что распределение материала по площади и глубине раскопа изменяется незначительно и различия касаются в основном редко встречающихся видов животных [46, с. 103]. Наибольшее количество фрагментов принадлежит лошади $(34,2 \%)$, далее идет мелкий рогатый скот $(33,6 \%)$, крупный рогатый скот $(26,4 \%)$ и свинья $(5,5 \%)$. На долю диких млекопитающих приходится $0,22 \%$ определимых костей [46, с. 102-103].

А. А. Романовым исследованы кости животных, полученные в 2014 и 2015 гг. [56, c. $168-176 ; 37$, с. 80 - 95; 30]. Основным результатом данных исследований можно считать выявление спецификации хозяйственной деятельности населения, проживавшего на разных участках памятника. Так, например, было выявлено, что в пределах раскопа № 1 2015 г. [37, с. 80 - 95; 29], расположенного на краю поселения близ одного из водотоков, опоясывающих площадку памятника с северной стороны, в четыре раза (с 0,81 до 3,26\%) по сравнению с центральными территориями городища возрастает доля костей птиц и более чем в 6,5 раза (с 0,63 до 4,22\%) доля костей и чешуи рыб. В пределах же раскопов 2012 - 2014 гг. была обнаружена площадка, на которой, по всей видимости, длительное время производилась обработка шкур пушных зверей. Концентрация костей этих видов промысловых животных здесь выше, чем на других участках территории городища [28; 56 , с. $168-176]$.

Остеологические материалы 2017 г. были изучены в институте экологии растений и животных УрО РАН (г. Екатеринбург) [27; 32]. В ходе исследования было установлено, что основным видом производящего хозяйства было разведение домашнего скота, охота же занимала небольшую роль в природопользовании населения городища. Доля костей промысловых видов животных составила $2,16 \%$ от общего количества определимых фрагментов [27, с. 168]. Описана зависимость распределения костей мелкого рогатого скота и лошади и керамического материала различных культурных типов по глубине раскопа. Изменения в составе стада домашних животных устойчиво коррелируют с изменением соотношения керамики основных представленных на городище археологических культур. Наблюдается уменьшение доли керамики бахмутинской культуры от нижних пластов к верхним [4]. Вместе с тем увеличивается доля керамики турбаслинской культуры и романовского типа. Одновременно с этим в пределах нижних пластов доля костей мелкого рогатого скота максимальна и затем устойчиво снижается с 45,49 до 18,42\%, доля же костей лошади возрастает с 24,24 до 41\%. Количество костей крупного рогатого скота и свиньи мало изменяется по глубине раскопа [31, рис. 1-2]. По методике Е. Е. Антипиной была рассчитана роль разных видов домашнего скота в рационе питания населения городища [1]. Полученные результаты свидетельствуют, что основную роль в мясном рационе на всем протяжении времени существования памятника играли лошадь и крупный рогатый скот [31, рис. 3]. Кроме того, выявлены различия в соотношении встречаемости костей разных отделов скелета у домашнего скота по глубине раскопа [31, рис. 4], что, как предполагают авторы, могло быть вызвано увеличением доли поступающего на городище мяса в разделанном виде извне. В материалах 2017 г. была встречена кость северного оленя [27, с. 171]. Данный вид уже описывался в остеологических кол- 
Электронный научный журнал (Online). ISSN 2303-9922. http://www.vestospu.ru

лекциях, полученных на памятниках Южного Предуралья эпохи средневековья [5], но на городище Уфа-2 ранее не встречался.

Отдельному исследованию были подвергнуты обнаруженные на городище кости рыб [45; 57-60]. В рамках этой работы был установлен видовой состав и размеры добываемых населением памятника рыб. Чаще всего добывались два вида рыб - белорыбица и сом $[59$, с. $174 ; 60$, с. 250$]$. Анализируя встречаемость костей разных отделов скелета, авторы статей пришли к выводу, что рыбы разделывались на территории городища [59, с. 174]. Была выдвинута гипотеза о развитости различных способов добычи рыбы населением региона, она основана на том, что виды рыб, чьи кости были встречены в пределах памятника, требуют различных способов добычи [60, с. 252]. В то же время авторы отмечают, что за все время проведения раскопок на городище найдено единственное грузило, которое можно однозначно интерпретировать как орудие рыбной ловли [59, с. 175]. Ранее А. М. Шевченко сообщал, что на памятнике выявлены спицы, используемые для плетения и починки сетей [57, с. 72]. В отчете П. Ф. Ищерикова [13, с. 13, рис. 9] встречены данные об обнаружении в культурном слое памятника рыболовного крючка и грузил. Однако автор пишет о возникшей дискуссии [13, с. 13-14]. Подобные грузила могли быть использованы как в рыбной ловле, так и для ткацких станков.

\section{Исследования бус и бисера}

Следующим важным исследованием материалов раскопа № 1 стал анализ бус и раковин каури, проведенный Р. Р. Руслановой [40; 41]. По предоставленным сведениям, коллекция изделий из стекла, полудрагоценных камней, раковин моллюсков и кораллов, полученных на территории памятника, насчитывает более 200 предметов и представлена в большей мере бусинами [41, с. 59]. Анализ позволил не только уточнить период попадания этих артефактов на городище, но и установить торговые пути, связывавшие его население с территориями Сирии, Крыма, Египта, побережья Индийского океана [42, с. 60-62]. Находки были датированы автором с III по VIII в. н.э. [41]. Ранее высказывалась гипотеза, что с торговыми караванами связано попадание на территорию городища костей верблюда [46, с. 102-103]. Однако анализ изотопов $\mathrm{Sr}$, проведенный М. Б. Медниковой на единственной кости верблюда из раскопа 2015 г., показал, что данное животное выпасалось по меньшей мере несколько лет на территории, геохимические условия которой схожи с Предуральем [23]. Тем не менее важно отметить, что данный анализ сделан на единственной кости и для построения каких-либо гипотез требуется продолжение исследований, для чего были отобраны образцы костей верблюда, найденные в раскопе 2017 г.

\section{Исследования каменного и костяного инвентаря}

В 2012 и 2015 гг. В. В. Руслановым [38; 39] и в 2017 г. В. М. Горожаниным [8] был проведен анализ разнообразного каменного инвентаря. В отчете об исследованиях материалов, полученных в 2012 и 2015 гг, автором дана подробная характеристика проанализированных орудий, выявлены предполагаемые места добычи пород, из которых выполнены каменные изделия, выдвинуты гипотезы о способе обработки и характере поступления каменного сырья на территорию памятника [38; 39]. В. В. Руслановым сделано предположение, что сбор подходящего сырья «являлся отраслью промысла насельников средневекового городища Уфа-II, которые могли отходить на 5-30 км в поисках подходящего каменного материала» [35, с. 142; 38].

В ходе исследования в слое городища было выявлено каменное изделие, являющееся, по предварительной гипотезе, фрагментом каменного жернова. Результаты его исследования в настоящий момент не опубликованы. 
Электронный научный журнал (Online). ISSN 2303-9922. http://www.vestospu.ru

Отдельно отметим изучение костяных изделий, обнаруженных на городище. В этих исследованиях анализу подвергались костяные накладки на лук [32] и подпружные пряжки [33]. Автору удалось установить, что использовавшиеся населением городища луки тюрко-хазарского типа и подпружные пряжки были занесены в лесостепное Предуралье, по всей видимости, вместе с миграционной волной носителей турбаслинской археологической культуры с территорий Восточного Приаралья [32, с. 75; 33, с. 285]. Также были проанализированы костяные наконечники стрел [36], дана их типология, в основании которой лежат способ крепления, форма и сечение пера, размеры. Авторы пришли к выводу о необходимости проведения глубоких исследований косторезного ремесла. Необходимо изучение полученного при раскопках на городище костяного инвентаря, включая изучение технико-технологических аспектов изготовления орудий, трасолого-экспериментальный анализ, исследование стратиграфо-планиграфического распределения изделий из кости и рога [36].

\section{Перспективные направления дальнейших исследований}

Проделана большая работа по изучению городища Уфа-2 и материалов, полученных в ходе полевых археологических исследований. Однако множество вопросов до сих пор требуют решения.

Наиболее актуальной является задача сведения воедино всех планиграфических и стратиграфических схем, полученных в процессе исследований на городище за все годы исследований, с целью построения единого плана городища, на котором были бы отражены все выявленные строения, мостовые и другие архитектурные объекты. Разработка такого плана позволила бы глубже осмыслить особенности распределения как археологических, так и естественнонаучных материалов.

Следующим важным моментом, на наш взгляд, является необходимость проведения анализа распределения керамики разных культурных групп по глубине раскопа. Сейчас эта работа проведена только для раскопа 2017 г., и ее результаты отразили, как происходила смена населения различных культур на городище в течение периода его функционирования, что позволило О. С. Белявской уточнить выдвинутую ранее гипотезу о причинах прекращения функционирования городища Уфа-2.

Как отмечалось выше, ряд исследователей отмечают назревшую необходимость глубокого изучения косторезного ремесла, широко распространенного на поселении.

В ходе изучения городища проведено большое количество естественнонаучных исследований (табл. 2). Однако перекрестного анализа между результатами археологических и естественнонаучных анализов практически не проводилось. Интеграция этих данных - важная задача, решение которой должно привести к более глубокому пониманию исторических процессов, происходивших на территории всего лесостепного Предуралья в эпоху раннего средневековья.

\section{Заключение}

Таким образом, в процессе исследований городища Уфа-2 был получен богатый и разнообразный материал, позволяющий утверждать, что данный памятник являлся крупным и хорошо укрепленным городищем эпохи раннего средневековья. Городище Уфа-2 - абсолютно уникальное явление для лесостепного Предуралья. Об этом свидетельствуют развитая фортификация и инфраструктура, широкие торгово-экономические связи, богатый, хорошо сохранившийся и стратифицированный культурный слой мощностью до 3-4 м. Возникновение памятника относится к IV в. н.э. Судя по керамике, основные отложения на его площадке относятся к бахмутинской (чандарский тип), именьковской (романовский тип) и турбаслинской культурам, менее представлены находки керамики кушнаренковской культуры и караякуповского типа. Богатство полученных материалов 
Электронный научный журнал (Online). ISSN 2303-9922. http://www.vestospu.ru

позволяет рассматривать городище в качестве модельного объекта для изучения различных аспектов хозяйства населения эпохи раннего средневековья всего лесостепного Предуралья.

Археозоологические исследования позволили установить, что основой хозяйства населения городища являлось животноводство, а охота, рыбная ловля и растениеводство, вероятно, были представлены в меньшей степени. Производящее хозяйство включало изготовление керамической посуды и изделий из камня, косторезное ремесло, литье из бронзы, прядение шерсти и кожевенное ремесло. Значимое место занимала торговля. Подтверждено наличие широких торговых связей между населением городища и регионами Азии, Крыма, Египта и др.

Дальнейшее изучение городища связано с более глубоким осмыслением полученных ранее данных. Начаты исследования особенностей хозяйства населения лесостепного Предуралья на разных этапах функционирования памятника. Было показано существование различий в составе стада домашнего скота по глубине культурного слоя, и эти изменения соотносятся с изменением процентного соотношения керамического материала бахмутинской, турбаслинской, именьковской (романовский тип) и кушнаренковской археологических культур в слое. Данные исследования проведены на одном, небольшом по площади участке раскопа 2017 г., и их продолжение требует сравнения материалов, полученных в других раскопах. Однако эта задача осложнена различиями в методиках проведения полевых археологических исследований и отсутствием единого плана напластований. Важным направлением дальнейших исследований является совместный анализ археологических, палинологических и остеологических материалов, полученных на разных раскопах.

Благодарности. Автор выражает благодарность руководству ГБУ РИКМЗ «Древняя Уфа», а также авторам научных отчетов О. С. Белявской, И. А. Шутелевой, Н. Б. Щербакову и М. Р. Шамсутдинову за предоставленную возможность использовать статистические и сводные данные.

\section{Список использованной литературы}

1. Антипина Е. Е. Состав древнего стада домашних животных: Логические аппроксимации // OPUS: Междисциплинарные исследования в археологии. М., 2008. Т. 6. С. 67-78.

2. Бахшиева А. К. Технико-технологические данные о керамике ОКН (памятник археологии) «Городище Уфа-ІІ» // Русланов Е. В., Шамсутдинов М. Р., Романов А. А. Раннесредневековые древности Уфимского полуострова. Городище Уфа-ІІ. Материалы археологических раскопок 2015 года. Уфа : Республиканский историко-культурный музей-заповедник «Древняя Уфа», 2016. С. 68-79.

3. Белявская (Крапачева) О. С. Научный отчет об итогах проведения охранных археологических полевых работ (археологические раскопки) на территории объекта культурного наследия «Городище Уфа-ІІ», расположенного в Кировском районе городского округа г. Уфа Республики Башкортостан, в 2017 году по Открытому листу № 615 от 01.06. 2017 г. Т. 1.202 с.; Т. 2.176 с.; Т. 3. 207 с.; Т. 4.137 с. // Архив ИА РАН. Ф-1. Р-1. № 61488-61491.

4. Белявская О. С., Проценко А. С. Керамический комплекс городища Уфа-ІІ как отражение этнокультурных процессов в эпоху Средневековья (по материалам раскопок 2017 года) // Древние и средневековые общества Евразии: перекресток культур. Международный научный симпозиум, посвященный памяти видного ученого-археолога, профессора, академика Академии наук Республики Башкортостан, доктора исторических наук Н. А. Мажитова / отв. ред. А. И. Уразова. Уфа, 6-7 дек. 2018 г. Уфа : Мир печати, 2018. C. $204-224$.

5. Гасилин В. В., Косинцев П. А. Вековая динамика фауны крупных млекопитающих Южного Урала // Вестник Оренбургского государственного университета. 2008. № 12. С. $90-94$.

6. Гарустович Г. Н., Овсянников В. В., Русланов Е. В. Городище Уфа-ІІ в золотоордынский период // Oriental Studies. 2018. Vol. 11, N 4 (38). P. 32—42. URL: https://kigiran.elpub.ru/jour/article/download/1329/1664. DOI: 10.22162/2619-0990-2018-39-4-32-42. 


\section{Электронный научный журнал (Online). ISSN 2303-9922. http://www.vestospu.ru}

7. Гольева А. А. Почвенные исследования раскопа Уфа-2 (раскопки 2015 года) // Шутелева И. А. Научный отчет об археологических исследованиях памятника федерального значения Городище Уфа II на территории Республики Башкортостан городского округа город Уфа, кварталов № 570 и 533 Кировского района, в 2015 г. по открытому листу № 1150. Уфа, 2016. Т. 1. С. 153-157 // Архив ИА РАН. Ф-1. Р-1. № 50334.

8. Горожанин В. М. Заключение о геологическом изучении археологического артефакта «Каменный жернов», обнаруженного на месте раскопок ОКН «Городище Уфа-ІІ» // Белявская (Крапачева) О. С. Научный отчет об итогах проведения охранных археологических полевых работ (археологические раскопки) на территории объекта культурного наследия «Городище Уфа-ІІ», расположенного в Кировском районе городского округа г. Уфа Республики Башкортостан, в 2017 году по Открытому листу № 615 от 01.06.2017. Т. 1. С. 114-117 // Архив ИА РАН. Ф-1. Р-1. № 61488.

9. Иванов В. А. Четыре монеты как эквивалент наличия городов в Башкирии в эпоху Золотой Орды (еще один пример современного археологического мифотворчества по материалам городища Уфа-II) // Золотоордынская цивилизация. 2012. Вып. 5. С. 404-414.

10. Исмагилов Р. Б. Научный отчет об итогах охранных раскопок городища Уфа-ІІ в Кировском районе административного округа г. Уфа в 2008 году : в 4 т. Т. 1. Уфа, 2009. 216 с. // Архив ИА РАН. Ф-1. Р-1. № 42931 .

11. Ишбирдин А. Р. Идентификация объектов органического происхождения и иных включений из культурного слоя городища Уфа-ІІ // Русланова (Тамимдарова) Р. Р. Научный отчет об итогах проведения археологических полевых работ (археологические раскопки) в г. Уфа на территории объекта культурного наследия «Городище Уфа-ІІ» в 2012 году. Уфа, 2017. Т. 2. С. 42—55 // Архив ИА РАН. Ф-1. Р-1. № 35573.

12. Ишбирдин А. Р. Идентификация объектов органического происхождения и иных включений из культурного слоя городища Уфа-ІІ // Белявская (Крапачева) О. С. Научный отчет об итогах проведения охранных археологических полевых работ (археологические раскопки) на территории объекта культурного наследия «Городище Уфа-ІІ», расположенного в Кировском районе городского округа г. Уфа Республики Башкортостан, в 2017 году по Открытому листу № 615 от 01.06.2017. Уфа, 2019. Т. 1. С. 106-113 // Архив ИА РАН. Ф-1. Р-1. № 61488.

13. Ищериков П. Ф. Городище Уфа-ІІ (раскопки 1957 г.). 1958. 22 с. // Научный архив УФИЦ РАН. Ф. 3. Оп. 2. Ед. хр. 374.

14. Ищериков П. Ф. Городище Уфа-ІІ // Башкирский археологический сборник. Уфа, 1959. С. $97-113$.

15. Колонских А. Г. Коллекция керамики городища Уфа-ІІ из раскопок Н. А. Мажитова 1958 года // Международный журнал гуманитарных и естественных наук. 2017. № 10. С. 9-24.

16. Курманов Р. Г. Изучение сукцессий растительных сообществ городища Уфа-ІІ методом споро-пыльцевого анализа // Вестник археологии, антропологии и этнографии. 2015. № 4 (31). С. $175-184$.

17. Курманов Р. Г. Реконструкция растительности городища Уфа-ІІ и прилегающих ландшафтов по материалам палинологического анализа // Белявская (Крапачева) О. С. Научный отчет об итогах проведения охранных археологических полевых работ (археологические раскопки) на территории объекта культурного наследия «Городище Уфа-ІІ», расположенного в Кировском районе городского округа г. Уфа Республики Башкортостан, в 2017 году по Открытому листу № 615 от 01.06.2017. Уфа, 2019. Т. 1. С. 136-151// Архив ИА РАН. Ф-1. Р-1. № 61488.

18. Курманов Р. Г., Ишбирдин А. Р. Реконструкция растительности на городище Уфа-ІІ и прилегающих ландшафтов по данным споро-пыльцевого анализа // Археология, этнография и антропология Евразии. 2015. T. 43, № 1. С. 101-109.

19. Куфтерин В. В. Антропологический материал из раскопок городища Уфа-II // Мажитов Н. А., Сунгатов Ф. А., Саттаров Т. Р., Султанова А. Н. Городище Уфа-ІІ. Материалы раскопок 2007 г. Уфа : ГУП «ГРИ “Башкортостан”», 2009. Т. 2. С. 221-222.

20. Матвеева Г. И., Никитина А. В. Особенности памятников романовского типа эпохи Великого переселения народов в северо-западной Башкирии на примере материалов исследования селища Романовка-II 1989 года // Вояджер: мир и человек. Теоретический и научно-методический журнал. Самара : Изд-во СамГТУ, 2015. № 5. С. 52-77.

21. Мажитов Н. А., Сунгатов Ф. А., Иванов В. А., Саттаров Т. Р., Султанова А. Н., Иванова Е. В. Городище Уфа-ІІ. Материалы раскопок 2006 г. Т. 1. Уфа : ГУП «ГРИ “Башкортостан”», 2007. 160 с.

22. Мажитов Н. А., Сунгатов Ф. А., Саттаров Т. Р., Султанова А. Н. Городище Уфа-ІІ: Материалы раскопок 2007 г. Т. 2. Уфа : ГУП «ГРИ “Башкортостан”», 2009. 224 с.

23. Медникова М. Б. Результаты изотопного анализа (Sr) // Русланов Е. В., Шамсутдинов М. Р., Романов А. А. Раннесредневековые древности Уфимского полуострова. Городище Уфа-ІІ. Материалы археологических раскопок 2015 года. Уфа : Республиканский историко-культурный музей-заповедник «Древняя Уфа», 2016. С. 109. 


\section{Электронный научный журнал (Online). ISSN 2303-9922. http://www.vestospu.ru}

24. Овсянников В. В. Раскопки городища Уфа-ІІ в 1990 году // Башкирский край. Уфа, 1992. Вып. 2. C. $65-79$.

25. Овсянников В. В. К вопросу об именьковском компоненте в материальной культуре городища Уфа-ІІ // Вояджер: мир и человек. Теоретический и научно-методический журнал. Самара : Изд-во СамГТУ, 2017. № 9. С. 32-42.

26. Овсянников В. В., Сунгатов Ф. А. Городище Каменная гора в среднем течении р. Уфы // Уфимский археологический вестник. 2004. Вып. 5. С. 230.

27. Пластеева Н. А., Девяшин М. М. Результаты изучения костных остатков млекопитающих городища Уфа-ІІ (материалы 2017 года раскопок) // Белявская (Крапачева) О. С. Научный отчет об итогах проведения охранных археологических полевых работ (археологические раскопки) на территории объекта культурного наследия «Городище Уфа-ІІ», расположенного в Кировском районе городского округа г. Уфа Республики Башкортостан, в 2017 году по Открытому листу № 615 от 01.06.2017. Уфа, 2019. Т. 1. С. 152—185 // Архив ИА РАН. Ф-1. Р-1. № 61488.

28. Романов А. А. Результаты изучения остатков животных из культурного слоя городища Уфа-II по материалам раскопок 2011-2012 гг. // Урал и просторы Евразии сквозь века и тысячелетия: научные публикации, посвящ. 80-летнему юбилею Н. А. Мажитова / отв. ред. А. Н. Султанова. Уфа : РИЦ БашГУ, 2013. С. $54-60$.

29. Романов А. А., Русланов Е. В. Кости млекопитающих и птиц из культурного слоя археологического памятника эпохи раннего средневековья «Городище Уфа-ІІ» (по материалам раскопок 2015 г). // VIII Башкирская археологическая конференция студентов и молодых ученых : материалы региональной науч. конф. Уфа : РИЦ БашГУ, 2015. С. 65-72.

30. Романов А. А., Шевченко А. М. Кости животных из культурного слоя археологического памятника раннего средневековья «Уфа-2» // Научные труды SWorld. Иваново : Научный мир, 2015. Т. 19, № 2 (39). C. $61-65$.

31. Романов А. А., Девяшин М. М., Пластеева Н. А., Белявская О. С. Млекопитающие в быту населения средневекового городища Уфа-ІІ // Вестник Томского государственного университета. История. [В печати].

32. Русланов Е. В. Костяные накладки луков средневекового городища Уфа-ІІ // Урал и просторы Евразии сквозь века и тысячелетия: научные публикации, посвящ. 80-летнему юбилею Н. А. Мажитова / отв. ред. А. Н. Султанова. Уфа : РИЦ БашГУ, 2013. С. 70-86.

33. Русланов Е. В. Роговые и костяные подпружные пряжки средневекового городища Уфа-II // Актуальные проблемы истории, этнологии, археологии и культуры Башкортостана : материалы Всерос. науч.-практ. конф. с междунар. участием, посвящ. юбилею видного общественного и научного деятеля, профессора Марата Махмутовича Кульшарипова / отв. ред. М. М. Кульшарипов, Б. В. Бурангулов. Уфа : РИЦ БашГУ, 2016. С. 282-288.

34. Русланов Е. В., Русланова Р. Р. Исследования раннесредневекового городища Уфа-ІІ в лесостепном Приуралье // Археологические открытия. 2015 год / отв. ред. Н. В. Лопатин. М. : Ин-т археологии РАН, 2017. С. $338-340$.

35. Русланов Е. В., Русланова Р. Р. Новые данные по камнеобработке у населения Уфимского полуострова в эпоху раннего средневековья по материалам городища Уфа-II // Мир Евразии: от древности к современности : сб. материалов Всерос. науч. конф. (Уфа, 16 марта 2018 г.) / отв. ред. Е. А. Круглов. Уфа : РИЦ БашГУ, 2018. Т. 1. С. 137-143.

36. Русланов Е. В., Русланова Р. Р. Костяные наконечники стрел средневекового городища Уфа-II // Этносы и культуры Урало-Поволжья: история и современность : материалы XII Всерос. науч.-практ. конф. молодых ученых / отв. ред. Э. В. Камалеев. Уфа : ИЭИ УФИЦ РАН, 2018. С. 101-146.

37. Русланов Е. В., Шамсутдинов М. Р., Романов А. А. Раннесредневековые древности Уфимского полуострова. Городище Уфа-ІІ. Материалы археологических раскопок 2015 года. Уфа : Республиканский историко-культурный музей-заповедник «Древняя Уфа», 2016. 276 с.

38. Русланов В. В. Результаты петрографического анализа каменных орудий // Русланов Е. В., Шамсутдинов М. Р., Романов А. А. Раннесредневековые древности Уфимского полуострова. Городище Уфа-ІІ. Материалы археологических раскопок 2015 года. Уфа : Республиканский историко-культурный музей-заповедник «Древняя Уфа», 2016. С. 64-67.

39. Русланов В. В. Предварительные результаты макроскопическо-петрографической диагностики каменных орудий средневекового городища Уфа-ІІ // Русланова (Тамимдарова) Р. Р. Научный отчет об итогах проведения охранных археологических полевых работ (археологические раскопки) в г. Уфа на территории объекта культурного наследия «Городище Уфа-ІІ» в 2012 г. по Открытому листу № 354 от 01.07.2012. Т. 2. Уфа, 2017. С. 37—42 // Архив ИА РАН. Ф-1. Р-1. № 35573. 


\section{Электронный научный журнал (Online). ISSN 2303-9922. http://www.vestospu.ru}

40. Русланова Р. Р. Анализ бус Городища Уфа-ІІ // Шутелева И. А., Щербаков Н. Б. Научный отчет о проведении археологических полевых работ на территории объекта культурного наследия регионального значения «Городище Уфа-ІІ, І тысячелетие н.э.», расположенного в квартале 570 городского округа Уфа Республики Башкортостан, в 2013 году по Открытому листу № 645. Уфа, 2013. Т. 1. С. 99—101 // Архив ИА РАН. Ф-1. Р-1. № 41691.

41. Русланова Р. Р. Морфолого-технологический и хронологический анализ бус // Русланов Е. В., Шамсутдинов М. Р., Романов А. А. Раннесредневековые древности Уфимского полуострова. Городище Уфа-ІІ. Материалы археологических раскопок 2015 года. Уфа, 2016. С. 59-63.

42. Русланова (Тамимдарова) Р. Р. Научный отчет об итогах проведения охранных археологических полевых работ (археологические раскопки) в г. Уфа на территории объекта культурного наследия «Городище Уфа-ІІ» в 2012 г. по Открытому листу № 354 от 1.07.2012. Т. 1. Уфа, 2017. 230 с. // Архив ИА РАН. Ф-1. Р-1. № 35572 .

43. Русланова Р. Р., Русланов Е. В., Белявская (Крапачева) О. С. Металлические изделия и относительная хронология средневекового городища Уфа-ІІ в лесостепном Приуралье // Вестник Томского государственного университета. История. 2019. № 58. С. 159-169. DOI: 10.17223/19988613/58/23.

44. Сатаев Р. М., Куфтерин В. В. Результаты археозоологических исследований на городище Уфа-ІІ // Русланова (Тамимдарова) Р. Р. Научный отчет об итогах проведения археологических полевых работ (археологические раскопки) в г. Уфа на территории объекта культурного наследия «Городище Уфа-ІІ» в 2012 г. Уфа, 2017. Т. 2. С. 58 - 60 // Архив ИА РАН. Ф-1. Р-1. № 35573.

45. Сатаев Р. М., Нурмухаметов И. М. Остатки млекопитающих и рыб из раскопок средневекового городища Уфа-II // Древность и средневековье Волго-Камья : материалы третьих Халиковских чтений. Казань : Болгар, 2004. С. 174-176.

46. Сатаев Р. М., Сатаева Л. В., Куфтерин В. В., Гимранов Д. О., Султанов Р. Р. Особенности природопользования средневекового населения Уфимского полуострова // Известия Самарского научного центра PAH. 2011. T. 13, № 5 (3). С. 101-105.

47. Сулейманов Р. Р. Характеристика почвенного покрова городища Уфа-ІІ // Мажитов Н. А., Сунгатов Ф. А., Саттаров Т. Р., Султанова А. Н. Городище Уфа-ІІ. Материалы раскопок 2007 г. Уфа : «ГРИ “Башкортостан”», 2009. Т. 2. С. 205-209.

48. Сулейманов Р. Р., Кунгурцев А. Я., Проценко А. С., Шутелева И. А., Щербаков Н. Б. Морфологические свойства почв археологических памятников г. Уфы (Республика Башкортостан) // Экобиотех. 2019. T. 2, № 4. С. 462-467.

49. Султанова А. Н. Отчет о научно-исследовательской работе «Итоги охранных археологических исследований городища Уфа-ІІ в Кировском районе городского округа г. Уфа Республики Башкортостан в 2010 году» (заключительный). Уфа, 2010. 66 с. // Архив ГБУ НПЦ Республики Башкортостан. НПЦ-ОАР-2.

50. Сунгатов Ф. А. Научный отчет об охранных раскопках городища Уфа-II в Кировском районе административного округа город Уфа Республики Башкортостан в 2008 году. Уфа, 2008. 63 с. // Архив ИА РАН. Ф-1. Р-1. № 43587.

51. Сунгатов Ф. А. Научный отчет об итогах охранных раскопок городища Уфа-ІІ в Кировском районе административного округа город Уфа Республики Башкортостан в 2009 году : в 2 т. Т. 1. Уфа, 2010. 237 с. // Архив ИА РАН. Ф-1. Р-1. № 37947.

52. Сунгатов Ф. А., Левченко В. А. Хронология средневекового городища Уфа-ІІ по данным радиоуглеродного датирования культурных отложений // Вестник Академии наук Республики Башкортостан. 2014. T. 19, № 1. С. 44-56.

53. Сунгатов Ф. А., Султанова А. Н., Бахшиева А. К., Мухаметдинов В. И., Русланова Р. Р., Русланов Е. В. К проблеме городов Южного Урала эпохи средневековья / сост. и науч. ред. Ф. А. Сунгатов. Уфа : Самрау, 2018. 335 с.

54. Шамсутдинов М. Р. Научный отчет об итогах проведения охранных археологических полевых работ (археологические раскопки) в г. Уфа на территории объекта культурного наследия «Городище Уфа-ІІ» в 2014 г. Т. 1. Уфа, 2015. 164 с. // Архив ИА РАН. Ф-1. Р-1. № 45204.

55. Шамсутдинов М. Р. Научный отчет об итогах проведения охранных археологических полевых работ (археологические раскопки) в г. Уфа на территории объекта культурного наследия «Городище Уфа-ІІ» в 2016 г. Т. 1. Уфа, 2018. 152 с. // Архив ИА РАН. Ф-1. Р-1. № 57731.

56. Шамсутдинов М. Р., Русланов Е. В., Романов А. А., Тагирова Р. Ш. Городище Уфа-ІІ. Материалы раскопок 2014 года. Уфа : ДизайнПресс, 2015. 320 с.

57. Шевченко А. М. Ихтиофауна среднего течения р. Белая по материалам раскопок средневекового городища Уфа-II // Аграрная Россия. М. : Фолиум, 2009. № S1. С. 71-72. 


\section{Электронный научный журнал (Online). ISSN 2303-9922. http://www.vestospu.ru}

58. Шевченко А. М. Палеоихтиологический анализ костного материала, обнаруженного в ходе археологических раскопок памятника археологии «Городище Уфа-ІІ» в 2017 году // Белявская (Крапачева) О. С. Научный отчет об итогах проведения охранных археологических полевых работ (археологические раскопки) на территории объекта культурного наследия «Городище Уфа-ІІ», расположенного в Кировском районе городского округа г. Уфа Республики Башкортостан, в 2017 году по Открытому листу № 615 от 01.06.2017. Уфа, 2019. Т. 1. С. 118 - 135 // Архив ИА РАН. Ф-1. Р-1. № 61488.

59. Шевченко А. М., Гимранов Д. О. Костные остатки рыб из средневекового городища Уфа-II по материалам раскопок 2014 г. // Экология древних и традиционных обществ : материалы V Междунар. науч. конф., Тюмень, 7-11 нояб. 2016 г. / под ред. д-ра ист. наук, проф. Н. П. Матвеевой. Тюмень : Тюмен. гос. ун-т, 2016. Вып. 5, ч. 1. С. $173-175$.

60. Шевченко А. М., Гимранов Д. О. Костные остатки рыб из средневекового городища Уфа-ІІ (по материалам раскопок 2015 года) // Динамика современных экосистем в голоцене : материалы IV Bcepoc. науч. конф. / [отв. ред. С. Н. Удальцов]. М. : Т-во науч. изд. КМК, 2016. С. 250-252.

61. Шутелева И. А. Научный отчет об археологических исследованиях памятника федерального значения Городище Уфа-ІІ на территории Республики Башкортостан городского округа город Уфа, кварталов № 570 и 533 Кировского района, в 2015 г. по открытому листу № 1150. Уфа, 2016. 181 с. // Архив ИА РАН. Ф-1. Р-1. № 50334 ; № 50335-50336 : Альбомы иллюстраций к отчету.

62. Шутелева И. А., Щербаков Н. Б. Научный отчет о проведении археологических полевых работ на территории объекта культурного наследия регионального значения «Городище Уфа-ІІ, I тысячелетие н.э.», расположенного в квартале 570 городского округа Уфа Республики Башкортостан, в 2013 году по Открытому листу № 645. Т. 1. Уфа, 2013. 141 с. // Архив ИА РАН. Ф-1. Р-1. № 41691.

63. Шутелева И. А., Щербаков Н. Б., Леонова Т. А., Шамсутдинов М. Р., Русланов Е. В. Уфа-ІІ - средневековое городище на Южном Урале. Материалы раскопок 2013 года. Уфа : Инеш, 2013. 192 с.

Поступила в редакцию 09.06.2020

Романов Алексей Александрович, аспирант

Институт истории, языка и литературы Уфимского федерального исследовательского центра РАН Российская Федерация, 450054, г. Уфа, пр-т Октября, 71

E-mail: romanov-aleksey-88@ya.ru 
Электронный научный журнал (Online). ISSN 2303-9922. http://www.vestospu.ru

\title{
UDC $902 / 904$
}

\section{A. A. Romanov}

\section{Natural science studies of early medieval strata of the Ufa-2 settlement}

The settlement Ufa-2 is one of the key archaeological monuments of the forest-steppe Cis-Urals. Archaeological research at the site was carried out from 1953 to 2018. In total, more than $2893 \mathrm{~m}^{2}$ were explored. The depth of the cultural layer reaches $3-4 \mathrm{~m}$. The site is associated with the population of mainly Bakhmutino (Chandar type), Turbasly and Imenkovo (Romanovka type) cultures. Less represented is the ceramic material of the Kushnarenkovo archaeological culture and the Karayakupovo type. According to the research data, the archaeological site dates back to the Middle Ages, however, the bulk of the objects found in the cultural layer belong to the period from the $4^{\text {th }}$ to the $9^{\text {th }}$ century AD. In the course of field archaeological work the layout of the residential part of the monument, the size and period of functioning of the fortifications were established. During the study of the settlement a large number of various natural scientific studies were carried out, however, no attempts were made to combine the results obtained in a single outline. For further study of the settlement, it is necessary to bring together the conclusions obtained in the course of field work and natural science research. In the process of studying osteological materials, the data were obtained on the composition and age structure of the herd, the role of hunting and fishing in the life support of the population. The productive economy included the manufacture of ceramic dishes and stone products, bone carving and leatherworking, bronze casting and wool spinning. Metal wares and beads made it possible to research the trade relations of the population of the Ufa Peninsula with the Volga, Prikamye, Syria, Crimea and Egypt. Based on palynological data, stages of succession of plant communities were established. In the final part of this work, the actual directions of further study of the settlement are formulated.

Key words: forest-steppe Cis Urals, settlement Ufa-2, Early Middle Ages, Bakhmutino culture, Turbasly culture, Kushnarenkovo culture, Romanovka type.

\author{
Romanov Aleksey Aleksandrovich, Postgraduate student \\ The Institution of History, Language and Literature of Ufa Federal Research Center of Russian Academy \\ of Science \\ Russian Federation, 450054, Ufa, pr-t Oktyabrya, 71 \\ E-mail: romanov-aleksey-88@ya.ru
}

\section{References}

1. Antipina E. E. Sostav drevnego stada domashnikh zhivotnykh: Logicheskie approksimatsii [Composition of an ancient herd of domestic animals: logical approximations]. OPUS: Mezhdistsiplinarnye issledovaniya $v$ arkheologii [OPUS: Interdisciplinary Research in Archeology]. Moscow, 2008, vol. 6, pp. 67-78. (In Russian)

2. Bakhshieva A. K. Tekhniko-tekhnologicheskie dannye o keramike OKN (pamyatnik arkheologii) "Gorodishche Ufa-II" [Technical and technological data on ceramics cultural heritage site (archeological monument) "Settlement Ufa-II"]. Ruslanov E. V., Shamsutdinov M. R., Romanov A. A. Rannesrednevekovye drevnosti Ufimskogo poluostrova. Gorodishche Ufa-II. Materialy arkheologicheskikh raskopok 2015 goda [Early medieval antiquities of the Ufa Peninsula. Settlement Ufa-II. 2015 archaeological site materials]. Ufa, Respublikanskii istoriko-kul'turnyi muzei-zapovednik "Drevnyaya Ufa" Publ., 2016, pp. 68-79. (In Russian)

3. Belyavskaya (Krapacheva) O. S. Nauchnyi otchet ob itogakh provedeniya okhrannykh arkheologicheskikh polevykh rabot (arkheologicheskie raskopki) na territorii ob"ekta kul'turnogo naslediya "Gorodishche Ufa-II", raspolozhennogo v Kirovskom raione gorodskogo okruga g. Ufa Respubliki Bashkortostan, v 2017 godu po Otkrytomu listu № 615 ot 01.06. 2017 g. T. 1. 202 s.; T. 2.176 s.; T. 3. 207 s.; T. 4.137 s. [Scientific report on the results of protective archaeological field work (archaeological excavations) on the territory of the cultural heritage site "Gorodishche Ufa-II", located in the Kirovsky district of the urban district of Ufa, the Republic of Bashkortostan, in 2017 according to Open sheet No. 615 dated 01.06. 2017. Vol. 1. 202 p.; Vol. 2. 176 p.; Vol. 3. 207 p.; Vol. 4. 137 p.]. Arkhiv IA RAN [Archive of the Institute of Archeology of the Russian Academy of Sciences]. F-1. R-1. № 61488-61491. (In Russian)

4. Belyavskaya O. S., Protsenko A. S. Keramicheskii kompleks gorodishcha Ufa-II kak otrazhenie etnokul'turnykh protsessov v epokhu Srednevekov'ya (po materialam raskopok 2017 goda) [Ceramic complex 


\section{Электронный научный журнал (Online). ISSN 2303-9922. http://www.vestospu.ru}

of the Ufa-II settlement as a reflection of ethnocultural processes in the Middle Ages (based on materials from excavations in 2017)]. Drevnie i srednevekovye obshchestva Evrazii: perekrestok kul'tur. Mezhdunarodnyi nauchnyi simpozium, posvyashchennyi pamyati vidnogo uchenogo-arkheologa, professora, akademika Akademii nauk Respubliki Bashkortostan, doktora istoricheskikh nauk N. A. Mazhitova. Ufa, 6-7 dek. 2018 g. [Ancient and medieval societies of Eurasia: the crossroads of cultures. International scientific symposium dedicated to the memory of a prominent scientist-archaeologist, professor, academician of the Academy of Sciences of the Republic of Bashkortostan, doctor of historical sciences N. A. Mazhitov. Ufa, 6-7 December. Oct. 2018]. Ufa, Mir pechati Publ., 2018, pp. 204-224. (In Russian)

5. Gasilin V. V., Kosintsev P. A. Vekovaya dinamika fauny krupnykh mlekopitayushchikh Yuzhnogo Urala [Secular dynamics of the fauna of large mammals of the Southern Urals]. Vestnik Orenburgskogo gosudarstvennogo universiteta - Vestnik of the Orenburg State University, 2008, no. 12, pp. 90-94. (In Russian)

6. Garustovich G. N., Ovsyannikov V. V., Ruslanov E. V. Gorodishche Ufa-II v zolotoordynskii period [The Ancient Settlement of Ufa-II in the Golden Horde Period]. Oriental Studies, 2018, vol. 11, no. 4 (38), pp. $32-42$. Available at: https://kigiran.elpub.ru/jour/article/download/1329/1664. DOI: 10.22162/2619-0990-2018-39-4-3242. (In Russian)

7. Gol'eva A. A. Pochvennye issledovaniya raskopa Ufa-2 (raskopki 2015 goda) [Soil research of the Ufa-2 excavation site (excavations in 2015)]. Shuteleva I. A. Nauchnyi otchet ob arkheologicheskikh issledovaniyakh pamyatnika federal'nogo znacheniya Gorodishche Ufa II na territorii Respubliki Bashkortostan gorodskogo okruga gorod Ufa, kvartalov № 570 i 533 Kirovskogo raiona, v 2015 g. po otkrytomu listu № 1150. Ufa, 2016. T. 1. S. 153-157 [Scientific report on archaeological research of a federal monument Ufa II settlement on the territory of the Republic of Bashkortostan, the city of Ufa, blocks No. 570 and 533 of the Kirovsky district, in 2015 according to Open sheet No. 1150 Ufa, 2016. Vol. 1, pp. 153-157]. Arkhiv IA RAN [Archive of the Institute of Archeology of the Russian Academy of Sciences]. F-1. R-1. № 50334. (In Russian)

8. Gorozhanin V. M. Zaklyuchenie o geologicheskom izuchenii arkheologicheskogo artefakta "Kamennyi zhernov", obnaruzhennogo na meste raskopok OKN "Gorodishche Ufa-II" [Conclusion on the geological study of the archaeological artifact "Stone millstone" discovered at the excavation site of the cultural heritage site "Gorodishche Ufa-II"]. Belyavskaya (Krapacheva) O. S. Nauchnyi otchet ob itogakh provedeniya okhrannykh arkheologicheskikh polevykh rabot (arkheologicheskie raskopki) na territorii ob"ekta kul'turnogo naslediya "Gorodishche Ufa-II", raspolozhennogo v Kirovskom raione gorodskogo okruga g. Ufa Respubliki Bashkortostan, v 2017 godu po Otkrytomu listu № 615 ot 01.06. 2017 g. T. 1. S. 114-117 [Scientific report on the results of protective archaeological field work (archaeological excavations) on the territory of the cultural heritage site "Gorodishche Ufa-II", located in the Kirovsky district of the urban district of Ufa, the Republic of Bashkortostan, in 2017 according to Open sheet No. 615 dated 01.06. 2017. Vol. 1, pp. 114-117]. Arkhiv IA RAN [Archive of the Institute of Archeology of the Russian Academy of Sciences]. F-1. R-1. № 61488. (In Russian)

9. Ivanov V. A. Chetyre monety kak ekvivalent nalichiya gorodov v Bashkirii v epokhu Zolotoi Ordy (eshche odin primer sovremennogo arkheologicheskogo mifotvorchestva po materialam gorodishcha Ufa-II) [Four coins, as an equivalent of existence of the cities in Bashkiria during an era of the Golden Horde (one more example of a modern archaeological myth creation on materials of the ancient settlement Ufa-II)]. Zolotoordynskaya tsivilizatsiya - Golden Horde Civilization, 2012, is. 5, pp. 404-414. (In Russian)

10. Ismagilov R. B. Nauchnyi otchet ob itogakh okhrannykh raskopok gorodishcha Ufa-II v Kirovskom raione administrativnogo okruga g. Ufa v 2008 godu: v 4 t. T. 1. Ufa, 2009. 216 s. [Scientific report on the results of security excavations of the Ufa-II settlement in the Kirovsky district of the administrative district of Ufa in 2008. In 4 vols. Vol. 1. Ufa, 2009. 216 p.]. Arkhiv IA RAN [Archive of the Institute of Archeology of the Russian Academy of Sciences]. F-1. R-1. № 42931. (In Russian)

11. Ishbirdin A. R. Identifikatsiya ob"ektov organicheskogo proiskhozhdeniya i inykh vklyuchenii iz kul'turnogo sloya gorodishcha Ufa-II [Identification of organic origin objects and other inclusions from the cultural layer of the Ufa-II settlement]. Ruslanova (Tamimdarova) R. R. Nauchnyi otchet ob itogakh provedeniya arkheologicheskikh polevykh rabot (arkheologicheskie raskopki) v g. Ufa na territorii ob"ekta kul'turnogo naslediya "Gorodishche Ufa-II" v 2012 godu. Ufa, 2017. T. 2. S. 42-55 [Scientific report on the results of archaeological field work (archaeological excavations) in Ufa on the territory of the cultural heritage site "Ufa-II Settlement" in 2012. Ufa, 2017. Vol. 2, pp. 42-55]. Arkhiv IA RAN [Archive of the Institute of Archeology of the Russian Academy of Sciences]. F-1. R-1. № 35573. (In Russian)

12. Ishbirdin A. R. Identifikatsiya ob"ektov organicheskogo proiskhozhdeniya i inykh vklyuchenii iz kul'turnogo sloya gorodishcha Ufa-II [Identification of objects of organic origin and other inclusions from the cultural layer of the Ufa-II settlement]. Belyavskaya (Krapacheva) O. S. Nauchnyi otchet ob itogakh provedeniya okhrannykh arkheologicheskikh polevykh rabot (arkheologicheskie raskopki) na territorii ob"ekta kul'turnogo naslediya "Gorodishche Ufa-II", raspolozhennogo v Kirovskom raione gorodskogo okruga g. Ufa Respubliki Bashkortostan, v 2017 godu po Otkrytomu listu № 615 ot 01.06. 2017 g. T. 1. S. 106-113 [Scientific report on 


\section{Электронный научный журнал (Online). ISSN 2303-9922. http://www.vestospu.ru}

the results of protective archaeological field work (archaeological excavations) on the territory of the cultural heritage site "Gorodishche Ufa-II", located in the Kirovsky district of the urban district of Ufa, the Republic of Bashkortostan, in 2017 according to Open sheet No. 615 dated 01.06. 2017. Vol. 1, pp. 106-113]. Arkhiv IA RAN [Archive of the Institute of Archeology of the Russian Academy of Sciences]. F-1. R-1. № 61488. (In Russian)

13. Ishcherikov P. F. Gorodishche Ufa-II (raskopki 1957 g.). 1958. 22 s. [Settlement Ufa-II (excavations in 1957). 1958. 22 p.]. Nauchnyi arkhiv UFITs RAN [Scientific archive of UFIC RAS]. F. 3. Op. 2. Ed. khr. 374. (In Russian)

14. Ishcherikov P. F. Gorodishche Ufa-II [Settlement Ufa-II]. Bashkirskii arkheologicheskii sbornik [Bashkir archaeological collection]. Ufa, 1959, pp. 97-113. (In Russian)

15. Kolonskikh A. G. Kollektsiya keramiki gorodishcha Ufa-II iz raskopok N. A. Mazhitova 1958 goda [Collection of ceramics from the Ufa-II settlement from the excavations of N. A. Mazhitov in 1958]. Mezhdunarodnyi zhurnal gumanitarnykh i estestvennykh nauk - International Journal of Humanities and Natural Sciences, 2017, no. 10, pp. 9-24. (In Russian)

16. Kurmanov R. G. Izuchenie suktsessii rastitel'nykh soobshchestv gorodishcha Ufa-II metodom sporopyl'tsevogo analiza [Studying of successions of plant communities from the settlement of Ufa II, using method of sporo-pollen analysis]. Vestnik arkheologii, antropologii i etnografii, 2015, no. 4 (31), pp. 175-184. (In Russian)

17. Kurmanov R. G. Rekonstruktsiya rastitel'nosti gorodishcha Ufa-II i prilegayushchikh landshaftov po materialam palinologicheskogo analiza [Reconstruction of the vegetation of the Ufa-II settlement and adjacent landscapes based on the materials of palynological analysis]. Belyavskaya (Krapacheva) O. S. Nauchnyi otchet ob itogakh provedeniya okhrannykh arkheologicheskikh polevykh rabot (arkheologicheskie raskopki) na territorii ob" ekta kul'turnogo naslediya "Gorodishche Ufa-II", raspolozhennogo v Kirovskom raione gorodskogo okruga g. Ufa Respubliki Bashkortostan, v 2017 godu po Otkrytomu listu № 615 ot 01.06. 2017 g. T. 1. S. 136-151 [Scientific report on the results of protective archaeological field work (archaeological excavations) on the territory of the cultural heritage site "Gorodishche Ufa-II", located in the Kirovsky district of the urban district of Ufa, the Republic of Bashkortostan, in 2017 according to Open sheet No. 615 dated 01.06.2017. Vol. 1, pp. 136-151]. Arkhiv IA RAN [Archive of the Institute of Archeology of the Russian Academy of Sciences]. F-1. R-1. № 61488. (In Russian)

18. Kurmanov R. G., Ishbirdin A. R. Rekonstruktsiya rastitel'nosti na gorodishche Ufa-II i prilegayushchikh landshaftov po dannym sporo-pyl'tsevogo analiza [Reconstruction of vegetation in the Ufa II hill fort and adjacent landscapes according to the spore-pollen analysis]. Arkheologiya, etnografiya $i$ antropologiya EvraziiArchaeology, Ethnology \& Anthropology of Eurasia, 2015, vol. 43, no. 1, pp. 101-109. (In Russian)

19. Kufterin V. V. Antropologicheskii material iz raskopok gorodishcha Ufa-II [Anthropological material from the excavations of the Ufa-II settlement]. Mazhitov N. A., Sungatov F. A., Sattarov T. R., Sultanova A. N. Gorodishche Ufa-II. Materialy raskopok $2007 \mathrm{~g}$. [Ufa-II settlement. Excavation materials 2007]. Ufa, GRI "Bashkortostan" Publ., 2009, vol. 2, pp. 221-222. (In Russian)

20. Matveeva G. I., Nikitina A. V. Osobennosti pamyatnikov romanovskogo tipa epokhi Velikogo pereseleniya narodov v severo-zapadnoi Bashkirii na primere materialov issledovaniya selishcha Romanovka-II 1989 goda [Features of Romanov-type monuments of the era of the Great Nations Migration in North-Western Bashkiria on the examples of materials from the study of the Romanovka-II village in 1989]. Voyadzher: mir $i$ chelovek. Teoreticheskii i nauchno-metodicheskii zhurnal. Samara, SamGTU Publ., 2015, no. 6, pp. 52 - 77. (In Russian)

21. Mazhitov N. A., Sungatov F. A., Ivanov V. A., Sattarov T. R., Sultanova A. N., Ivanova E. V. Gorodishche Ufa-II. Materialy raskopok 2006 g. T. 1 [Settlement Ufa-II. Excavation materials 2006. Vol. 1]. Ufa, GRI "Bashkortostan" Publ., 2007. 160 p. (In Russian)

22. Mazhitov N. A., Sungatov F. A., Sattarov T. R., Sultanova A. N. Gorodishche Ufa-II: Materialy raskopok 2007 g. T. 2 [Settlement Ufa-II. Excavation materials 2007. Vol. 2]. Ufa, GRI “Bashkortostan” Publ., 2009. 224 p. (In Russian)

23. Mednikova M. B. Rezul'taty izotopnogo analiza (Sr) [Results of isotope analysis (Sr)]. Ruslanov E. V., Shamsutdinov M. R., Romanov A. A. Rannesrednevekovye drevnosti Ufimskogo poluostrova. Gorodishche Ufa-II. Materialy arkheologicheskikh raskopok 2015 goda [Early medieval antiquities of the Ufa Peninsula. Settlement Ufa-II. 2015 archaeological site materials]. Ufa, Respublikanskii istoriko-kul'turnyi muzei-zapovednik "Drevnyaya Ufa" Publ., 2016, p. 109. (In Russian)

24. Ovsyannikov V. V. Raskopki gorodishcha Ufa-II v 1990 godu [Excavations of the Ufa-II settlement in 1990]. Bashkirskii krai [Bashkir Territory]. Ufa, 1992. Is. 2, pp. 65-79. (In Russian)

25. Ovsyannikov V. V. K voprosu ob imen'kovskom komponente v material'noi kul'ture gorodishcha Ufa-II [To the question about the Imenkovo component in the material culture of the Ufa II settlement]. Voyadzher: mir i chelovek. Teoreticheskii i nauchno-metodicheskii zhurnal. Samara, SamGTU Publ., 2017, no. 9, pp. 32-42. (In Russian) 


\section{Электронный научный журнал (Online). ISSN 2303-9922. http://www.vestospu.ru}

26. Ovsyannikov V. V., Sungatov F. A. Gorodishche Kamennaya gora v srednem techenii r. Ufy [The settlement Kamennaya Gora in the middle reaches of the Ufa river]. Ufimskii arkheologicheskii vestnik - The Ufa Archaeological Herald, 2004, is. 5, pp. 230. (In Russian)

27. Plasteeva N. A., Devyashin M. M. Rezul'taty izucheniya kostnykh ostatkov mlekopitayushchikh gorodishcha Ufa-II (materialy 2017 goda raskopok) [Results of the study of bone remains of mammals of the Ufa-II settlement (materials of 2017 excavations)]. Belyavskaya (Krapacheva) O. S. Nauchnyi otchet ob itogakh provedeniya okhrannykh arkheologicheskikh polevykh rabot (arkheologicheskie raskopki) na territorii ob"ekta kul'turnogo naslediya "Gorodishche Ufa-II", raspolozhennogo v Kirovskom raione gorodskogo okruga g. Ufa Respubliki Bashkortostan, v 2017 godu po Otkrytomu listu № 615 ot 01.06. 2017 g. T. 1. S. 152-185 [Scientific report on the results of protective archaeological field work (archaeological excavations) on the territory of the cultural heritage site "Gorodishche Ufa-II", located in the Kirovsky district of the urban district of Ufa, the Republic of Bashkortostan, in 2017 according to Open sheet No. 615 dated 01.06. 2017. Vol. 1, pp. 152-185]. Arkhiv IA RAN [Archive of the Institute of Archeology of the Russian Academy of Sciences]. F-1. R-1. № 61488. (In Russian)

28. Romanov A. A. Rezul'taty izucheniya ostatkov zhivotnykh iz kul'turnogo sloya gorodishcha Ufa-II po materialam raskopok 2011-2012 gg. [Results of studying the remains of animals from the cultural layer of the Ufa-II settlement based on materials from excavations in 2011-2012]. Ural i prostory Evrazii skvoz' veka i tysyacheletiya: nauchnye publikatsii, posvyashch. 80-letnemu yubileyu N. A. Mazhitova [Ural and Eurasian expanses through centuries and millennia: scientific publications dedicated to $80^{\text {th }}$ anniversary of $\mathrm{N}$. A. Mazhitov]. Ufa, RITs BashGU Publ., 2013, pp. 54 - 60. (In Russian)

29. Romanov A. A., Ruslanov E. V. Kosti mlekopitayushchikh i ptits iz kul'turnogo sloya arkheologicheskogo pamyatnika epokhi rannego srednevekov'ya "Gorodishche Ufa-II" (po materialam raskopok 2015 g.) [Bones of mammals and birds from the cultural layer of the archaeological site of the early Middle Ages "Settlement UfaII" (based on materials from 2015 excavations)]. VIII Bashkirskaya arkheologicheskaya konferentsiya studentov $i$ molodykh uchenykh: materialy regional'noi nauch. konf. [VIII Bashkir archaeological conference of students and young scientists. Proceed. of regional sci. conf.]. Ufa, RITs BashGU Publ., 2015, pp. 65-72. (In Russian)

30. Romanov A. A., Shevchenko A. M. Kosti zhivotnykh iz kul'turnogo sloya arkheologicheskogo pamyatnika rannego srednevekov'ya "Ufa-2" [Animal bones from the cultural layer of the archaeological site of the early Middle Ages "Ufa-2"]. Nauchnye trudy SWorld. Ivanovo, Nauchnyi mir Publ., 2015, vol. 19, no. 2 (39), pp. 61-65. (In Russian)

31. Romanov A. A., Devyashin M. M., Plasteeva N. A., Belyavskaya O. S. Mlekopitayushchie v bytu naseleniya srednevekovogo gorodishcha Ufa-II [Mammals in the life of the population of the medieval settlement Ufa-II]. Vestnik Tomskogo gosudarstvennogo universiteta. Istoriya - Tomsk State University Journal of History. (In print). (In Russian)

32. Ruslanov E. V. Kostyanye nakladki lukov srednevekovogo gorodishcha Ufa-II [Bone onions of bows of the medieval settlement of Ufa-II]. Ural i prostory Evrazii skvoz'veka i tysyacheletiya: nauchnye publikatsii, posvyashch. 80-letnemu yubileyu N. A. Mazhitova [Urals and the expanses of Eurasia through centuries and millennia: scientific publications dedicated to $80^{\text {th }}$ anniversary of N. A. Mazhitov]. Ufa, RITs BashGU Publ., 2013, pp. 70-86. (In Russian)

33. Ruslanov E. V. Rogovye i kostyanye podpruzhnye pryazhki srednevekovogo gorodishcha Ufa-II [Horn and bone girth buckles of the medieval settlement of Ufa-II]. Aktual'nye problemy istorii, etnologii, arkheologii $i$ kul'tury Bashkortostana: materialy Vseros. nauch.-prakt. konf. s mezhdunar. uchastiem, posvyashch. yubileyu vidnogo obshchestvennogo i nauchnogo deyatelya, professora Marata Makhmutovicha Kul'sharipova [Actual problems of history, ethnology, archeology and culture of Bashkortostan. Proceed. of the All-Russia sci.-pract. conf. with internat. participation, dedicated anniversary of a prominent public and scientific figure, professor Marat M. Kulsharipov]. Ufa, RITs BashGU Publ., 2016, pp. 282-288. (In Russian)

34. Ruslanov E. V., Ruslanova R. R. Issledovaniya rannesrednevekovogo gorodishcha Ufa-II v lesostepnom Priural'e [Research of the early medieval settlement Ufa-II in the forest-steppe Urals]. Arkheologicheskie otkrytiya. 2015 god [Archaeological discoveries. 2015]. Moscow, In-t arkheologii RAN Publ., 2017. pp. 338-340. (In Russian)

35. Ruslanov E. V., Ruslanova R. R. Novye dannye po kamneobrabotke u naseleniya Ufimskogo poluostrova $\mathrm{v}$ epokhu rannego srednevekov'ya po materialam gorodishcha Ufa-II [New data on stone processing among the population of the Ufa Peninsula in the early Middle Ages based on materials from the settlement of Ufa-II]. Mir Evrazii: ot drevnosti k sovremennosti: sb. materialov Vseros. nauch. konf. (Ufa, 16 marta 2018 g.) [World of Eurasia: from antiquity to modernity. Proceed. of All-Russia sci. conf. (Ufa, March 16, 2018)]. Ufa, RITs BashGU Publ., 2018, vol. 1, pp. 137-143. (In Russian) 


\section{Электронный научный журнал (Online). ISSN 2303-9922. http://www.vestospu.ru}

36. Ruslanov E. V., Ruslanova R. R. Kostyanye nakonechniki strel srednevekovogo gorodishcha Ufa-II [Bone arrowheads of the medieval settlement of Ufa-II]. Etnosy i kul'tury Uralo-Povolzh'ya: istoriya i sovremennost': materialy XII Vseros. nauch.-prakt. konf. molodykh uchenykh [Ethnos and cultures of the Ural-Volga region: history and modernity. Proceed. of the XII All-Russia sci.-pract. conf. young scientists]. Ufa, IEI UFITs RAN Publ., 2018, pp. 101-146. (In Russian)

37. Ruslanov E. V., Shamsutdinov M. R., Romanov A. A. Rannesrednevekovye drevnosti Ufimskogo poluostrova. Gorodishche Ufa-II. Materialy arkheologicheskikh raskopok 2015 goda [Early medieval antiquities of the Ufa Peninsula. Settlement Ufa-II. 2015 archaeological site proceedings]. Ufa, Respublikanskii istorikokul’turnyi muzei-zapovednik “Drevnyaya Ufa” Publ., 2016. 276 p. (In Russian)

38. Ruslanov V. V. Rezul'taty petrograficheskogo analiza kamennykh orudii [Results of petrographic analysis of stone tools]. Ruslanov E. V., Shamsutdinov M. R., Romanov A. A. Rannesrednevekovye drevnosti Ufimskogo poluostrova. Gorodishche Ufa-II. Materialy arkheologicheskikh raskopok 2015 goda [Early medieval antiquities of the Ufa Peninsula. Settlement Ufa-II. 2015 archaeological site proceedings]. Ufa, Respublikanskii istorikokul'turnyi muzei-zapovednik "Drevnyaya Ufa" Publ., 2016, pp. 64-67. (In Russian)

39. Ruslanov V. V. Predvaritel'nye rezul'taty makroskopichesko-petrograficheskoi diagnostiki kamennykh orudii srednevekovogo gorodishcha Ufa-II [Preliminary results of macroscopic-petrographic diagnostics of stone tools of the medieval settlement of Ufa-II]. Ruslanova (Tamimdarova) R. R. Nauchnyi otchet ob itogakh provedeniya okhrannykh arkheologicheskikh polevykh rabot (arkheologicheskie raskopki) v g. Ufa na territorii ob"ekta kul'turnogo naslediya “Gorodishche Ufa-II” v 2012 g. po Otkrytomu listu № 354 ot 01.07.2012. T. 2 [Scientific report on the results of protective archaeological field work (archaeological excavations) in the city of Ufa on the territory of the cultural heritage site "Settlement Ufa-II" in 2012 according to Open sheet No. 354 dated 1.07.2012. Vol. 2]. Ufa, 2017, pp. 37-42. Arkhiv IA RAN [Archive of the Institute of Archeology of the Russian Academy of Sciences]. F-1. R-1. № 35573. (In Russian)

40. Ruslanova R. R. Analiz bus Gorodishcha Ufa-II [Analysis of the beads of the Ufa-II settlement]. Shuteleva I. A., Shcherbakov N. B. Nauchnyi otchet o provedenii arkheologicheskikh polevykh rabot na territorii ob"ekta kul'turnogo naslediya regional'nogo znacheniya "Gorodishche Ufa-II, I tysyacheletie n.e.", raspolozhennogo v kvartale 570 gorodskogo okruga Ufa Respubliki Bashkortostan, v 2013 godu po Otkrytomu listu № 645 [Scientific report on the conduct of archaeological field work on the territory of the cultural heritage site of regional significance "Settlement Ufa-II, I millennium AD", located in quarter 570 of the Ufa city district of the Republic of Bashkortostan in 2013 according to Open sheet No. 645]. Ufa, 2013. Vol. 1, pp. 99-101. Arkhiv IA RAN [Archive of the Institute of Archeology of the Russian Academy of Sciences]. F-1. R-1. № 41691. (In Russian)

41. Ruslanova R. R. Morfologo-tekhnologicheskii i khronologicheskii analiz bus [Morphological, technological and chronological analysis of beads]. Ruslanov E. V., Shamsutdinov M. R., Romanov A. A. Rannesrednevekovye drevnosti Ufimskogo poluostrova. Gorodishche Ufa-II. Materialy arkheologicheskikh raskopok 2015 goda [Early medieval antiquities of the Ufa Peninsula. Settlement Ufa-II. 2015 archaeological site proceedings]. Ufa, Respublikanskii istoriko-kul'turnyi muzei-zapovednik "Drevnyaya Ufa” Publ., 2016, pp. 59 —63. (In Russian)

42. Ruslanova (Tamimdarova) R. R. Nauchnyi otchet ob itogakh provedeniya okhrannykh arkheologicheskikh polevykh rabot (arkheologicheskie raskopki) v g. Ufa na territorii ob" ekta kul'turnogo naslediya "Gorodishche Ufa-II” v 2012 g. po Otkrytomu listu № 354 ot 01.07.2012. T. 1. Ufa, 2017. 230 s. [Scientific report on the results of protective archaeological field work (archaeological excavations) in the city of Ufa on the territory of the cultural heritage site "Settlement Ufa-II" in 2012 according to Open sheet No. 354 dated 1.07.2012. Vol. 1. Ufa, 2017. 230 p.]. Arkhiv IA RAN [Archive of the Institute of Archeology of the Russian Academy of Sciences]. F-1. R-1. № 35572. (In Russian)

43. Ruslanova R. R., Ruslanov E. V., Belyavskaya (Krapacheva) O. S. Metallicheskie izdeliya i otnositel'naya khronologiya srednevekovogo gorodishcha Ufa-II v lesostepnom Priural'e [Metal products and relative chronology of the medieval settlement Ufa-II in the Forest-Steppe Urals]. Vestnik Tomskogo gosudarstvennogo universiteta. Istoriya - Tomsk State University Journal of History, 2019, no. 58, pp. 159-169. DOI: 10.17223/19988613/58/23. (In Russian)

44. Sataev R. M., Kufterin V. V. Rezul'taty arkheozoologicheskikh issledovanii na gorodishche Ufa-II [Results of archaeozoological studies at the Ufa-II settlement]. Ruslanova (Tamimdarova) R. R. Nauchnyi otchet ob itogakh provedeniya arkheologicheskikh polevykh rabot (arkheologicheskie raskopki) v g. Ufa na territorii ob "ekta kul'turnogo naslediya "Gorodishche Ufa-II" v $2012 \mathrm{~g}$. [Scientific report on the results of archaeological field work (archaeological excavations) in Ufa on the territory of the cultural heritage site Ufa-II settlement in 2012]. Ufa, 2017, vol. 2, pp. 58-60. Arkhiv IA RAN [Archive of the Institute of Archeology of the Russian Academy of Sciences]. F-1. R-1. № 35573. (In Russian) 


\section{Электронный научный журнал (Online). ISSN 2303-9922. http://www.vestospu.ru}

45. Sataev R. M., Nurmukhametov I. M. Ostatki mlekopitayushchikh i ryb iz raskopok srednevekovogo gorodishcha Ufa-II [Remains of mammals and fish from the excavations of the medieval settlement of Ufa-II]. Drevnost'i srednevekov'e Volgo-Kam'ya: materialy tret'ikh Khalikovskikh chtenii [Antiquity and the Middle Ages of the Volga-Kama. Proceed. of the $3^{\text {rd }}$ Khalikov readings]. Kazan, Bolgar, 2004, pp. 174-176. (In Russian)

46. Sataev R. M., Sataeva L. V., Kufterin V. V., Gimranov D. O., Sultanov R. R. Osobennosti prirodopol'zovaniya srednevekovogo naseleniya Ufimskogo poluostrova [Features of nature management of the medieval population of the Ufa peninsula]. Izvestiya Samarskogo nauchnogo tsentra RAN - Izvestia of Samara Scientific Center of the Russian Academy of Sciences, 2011, vol. 13, no. 5 (3), pp. 101-105. (In Russian)

47. Suleimanov R. R. Kharakteristika pochvennogo pokrova gorodishcha Ufa-II [Characteristics of the soil cover of the Ufa-II settlement]. Mazhitov N. A., Sungatov F. A., Sattarov T. R., Sultanova A. N. Gorodishche UfaII. Materialy raskopok 2007 g. [Ufa-II settlement. Excavation materials 2007]. Ufa, GRI "Bashkortostan" Publ., 2009, vol. 2, pp. 205-209. (In Russian)

48. Suleimanov R. R., Kungurtsev A. Ya., Protsenko A. S., Shuteleva I. A., Shcherbakov N. B. Morfologicheskie svoistva pochv arkheologicheskikh pamyatnikov g. Ufy (Respublika Bashkortostan) [Morphological properties of soils of archaeological monuments of Ufa city (Republic of Bashkortostan)]. Ekobiotekh - Ecobiotech, 2019, vol. 2, no. 4, pp. 462-467. (In Russian)

49. Sultanova A. N. Otchet o nauchno-issledovatel'skoi rabote "Itogi okhrannykh arkheologicheskikh issledovanii gorodishcha Ufa-II v Kirovskom raione gorodskogo okruga g. Ufa Respubliki Bashkortostan v 2010 godu" (zaklyuchitel'nyi). Ufa, 2010. 66 s. [Report on the research work "Results of protective archaeological research of the Ufa-II settlement in the Kirovsky district of the Ufa city district of the Republic of Bashkortostan in 2010" (final). Ufa, 2010. 66 p.]. Arkhiv GBU NPTs Respubliki Bashkortostan [Archive of GBU SPC of the Republic of Bashkortostan]. NPTs-OAR-2. (In Russian)

50. Sungatov F. A. Nauchnyi otchet ob okhrannykh raskopkakh gorodishcha Ufa-II v Kirovskom raione administrativnogo okruga goroda Ufa Respubliki Bashkortostan v 2008 godu. Ufa, 2008. 63 p. [Scientific report on the security excavations of the Ufa-II settlement in the Kirovsky district of the Ufa administrative district of the Republic of Bashkortostan in 2008]. Arkhiv IA RAN [Archive of the Institute of Archeology of the Russian Academy of Sciences]. F-1. R-1. № 43587. (In Russian)

51. Sungatov F. A. Nauchnyi otchet ob itogakh okhrannykh raskopok gorodishcha Ufa-II v Kirovskom raione administrativnogo okruga gorod Ufa Respubliki Bashkortostan v 2009 godu: v 2 t. T. 1. Ufa, 2010. 237 p. [Scientific report on the results of security excavations of the Ufa-II settlement in the Kirovsky district of the administrative district of the city of Ufa of the Republic of Bashkortostan in 2009. In 2 vols. Vol. 1]. Arkhiv IA RAN [Archive of the Institute of Archeology of the Russian Academy of Sciences]. F-1. R-1. № 37947. (In Russian)

52. Sungatov F. A., Levchenko V. A. Khronologiya srednevekovogo gorodishcha Ufa-II po dannym radiouglerodnogo datirovaniya kul'turnykh otlozhenii [Chronology of the medieval settlement Ufa II according to the radiocarbon dating of cultural deposits]. Vestnik Akademii nauk Respubliki Bashkortostan - The Herald of the Academy of Sciences of the Republic of Bashkortostan, 2014, vol. 19, no. 1, pp. 44-56. (In Russian)

53. Sungatov F. A., Sultanova A. N., Bakhshieva A. K., Mukhametdinov V. I., Ruslanova R. R., Ruslanov E. V. K probleme gorodov Yuzhnogo Urala epokhi srednevekov'ya [On the problem of the cities of the Southern Urals in the Middle Ages]. Ufa, Samrau Publ., 2018. 335 p. (In Russian)

54. Shamsutdinov M. R. Nauchnyi otchet ob itogakh provedeniya okhrannykh arkheologicheskikh polevykh rabot (arkheologicheskie raskopki) v g. Ufa na territorii ob"ekta kul'turnogo naslediya "Gorodishche UfaII" v 2014 g. T. 1. Ufa, 2015. 164 p. [Scientific report on the results of protective archaeological field work (archaeological excavations) in the city of Ufa on the territory of the cultural heritage site "Gorodishche Ufa-II" in 2014. Vol. 1]. Arkhiv IA RAN [Archive of the Institute of Archeology of the Russian Academy of Sciences]. F-1. R-1. № 45204. (In Russian)

55. Shamsutdinov M. R. Nauchnyi otchet ob itogakh provedeniya okhrannykh arkheologicheskikh polevykh rabot (arkheologicheskie raskopki) v g. Ufa na territorii ob"ekta kul'turnogo naslediya "Gorodishche UfaII" v 2016 g. T. 1. Ufa, 2018. 152 p. [Scientific report on the results of protective archaeological field work (archaeological excavations) in Ufa on the territory of the cultural heritage site "Gorodishche Ufa-II" in 2016. Vol. 1]. Arkhiv IA RAN [Archive of the Institute of Archeology of the Russian Academy of Sciences]. F-1. R-1. № 57731. (In Russian)

56. Shamsutdinov M. R., Ruslanov E. V., Romanov A. A., Tagirova R. Sh. Gorodishche Ufa-II. Materialy raskopok 2014 goda [Settlement Ufa-II. Excavation materials 2014]. Ufa, DizainPress Publ., 2015. 320 p. (In Russian)

57. Shevchenko A. M. Ikhtiofauna srednego techeniya r. Belaya po materialam raskopok srednevekovogo gorodishcha Ufa-II [Ichthyofauna of the middle reaches of the Belaya river on the materials of excavations of the medieval settlement Ufa-II]. Agrarnaya Rossiya [Agrarian Russia]. Moscow, Folium Publ., 2009, no. S1, pp. 71-72. (In Russian) 


\section{Электронный научный журнал (Online). ISSN 2303-9922. http://www.vestospu.ru}

58. Shevchenko A. M. Paleoikhtiologicheskii analiz kostnogo materiala, obnaruzhennogo v khode arkheologicheskikh raskopok pamyatnika arkheologii "Gorodishche Ufa-II" v 2017 godu [Paleoichthyological analysis of bone material found during archaeological excavations of the archaeological site "Settlement Ufa-II" in 2017]. Belyavskaya (Krapacheva) O. S. Nauchnyi otchet ob itogakh provedeniya okhrannykh arkheologicheskikh polevykh rabot (arkheologicheskie raskopki) na territorii ob"ekta kul'turnogo naslediya "Gorodishche UfaII”, raspolozhennogo v Kirovskom raione gorodskogo okruga g. Ufa Respubliki Bashkortostan, v 2017 godu po Otkrytomu listu № 615 ot 01.06. 2017 g. T. 1. S. 118-135 [Scientific report on the results of protective archaeological field work (archaeological excavations) on the territory of the cultural heritage site "Gorodishche Ufa-II", located in the Kirovsky district of the urban district of Ufa, the Republic of Bashkortostan, in 2017 according to Open sheet No. 615 dated 01.06. 2017. Vol. 1, pp. 118-135]. Arkhiv IA RAN [Archive of the Institute of Archeology of the Russian Academy of Sciences]. F-1. R-1. № 61488. (In Russian)

59. Shevchenko A. M., Gimranov D. O. Kostnye ostatki ryb iz srednevekovogo gorodishcha Ufa-II po materialam raskopok $2014 \mathrm{~g}$. [Bone remains of fish from the medieval settlement of Ufa-II based on materials from excavations in 2014]. Ekologiya drevnikh i traditsionnykh obshchestv: materialy V Mezhdunar. nauch. konf., Tyumen, 7-11 noyab. 2016 g. [Ecology of ancient and traditional societies. Proceed. of the V Internat. sci. conf., Tyumen, 7-11 Nov. 2016]. Tyumen, Tyumen. gos. un-t Publ., 2016, is. 5, part 1, pp. 173-175. (In Russian)

60. Shevchenko A. M., Gimranov D. O. Kostnye ostatki ryb iz srednevekovogo gorodishcha Ufa-II (po materialam raskopok 2015 goda) [Bone remains of fish from the medieval settlement of Ufa-II (based on materials from excavations in 2015)]. Dinamika sovremennykh ekosistem v golotsene: materialy IV Vseros. nauch. konf. [Dynamics of modern ecosystems in the Holocene. Proceed. of the IV All-Russia sci. conf.]. Moscow, T-vo nauch. izd. KMK Publ., 2016, pp. 250-252. (In Russian)

61. Shuteleva I. A. Nauchnyi otchet ob arkheologicheskikh issledovaniyakh pamyatnika federal'nogo znacheniya Gorodishche Ufa-II na territorii Respubliki Bashkortostan gorodskogo okruga gorod Ufa, kvartalov № 570 i 533 Kirovskogo raiona, v 2015 g. po otkrytomu listu № 1150. Ufa, 2016. 181 p. [Scientific report on archaeological research of a federal monument Ufa-II settlement on the territory of the Republic of Bashkortostan, Ufa city district, blocks 570 and 533 of Kirovsky district, in 2015 according to Open sheet No. 1150]. Arkhiv IA RAN [Archive of the Institute of Archeology of the Russian Academy of Sciences]. F-1. R-1. № 50334; № 50335-50336: Al’bomy illyustratsii k otchetu. (In Russian)

62. Shuteleva I. A., Shcherbakov N. B. Nauchnyi otchet o provedenii arkheologicheskikh polevykh rabot na territorii ob" ekta kul'turnogo naslediya regional'nogo znacheniya “Gorodishche Ufa-II, I tysyacheletie n.e.", raspolozhennogo v kvartale 570 gorodskogo okruga Ufa Respubliki Bashkortostan, v 2013 godu po Otkrytomu listu № 645. T. 1. Ufa, 2013. 141 s. [Scientific report on the conduct of archaeological field work on the territory of the cultural heritage site of regional significance "Settlement Ufa-II, I millennium AD", located in quarter 570 of the Ufa city district of the Republic of Bashkortostan, in 2013 according to Open sheet No. 645. Vol. 1]. Arkhiv IA RAN [Archive of the Institute of Archeology of the Russian Academy of Sciences]. F-1. R-1. № 41691. (In Russian)

63. Shuteleva I. A., Shcherbakov N. B., Leonova T. A., Shamsutdinov M. R., Ruslanov E. V. Ufa-II srednevekovoe gorodishche na Yuzhnom Urale. Materialy raskopok 2013 goda [Ufa-II is a medieval settlement in the South Urals. Excavation materials of 2013]. Ufa, Inesh Publ., 2013. 192 p. (In Russian) 